\title{
Fission Product Inventory and Burnup Evaluation by Gamma Spectrometry of the AGR-2 Irradiation
}

The INL is a

U.S. Department of Energy

National Laboratory

operated by

Battelle Energy Alliance

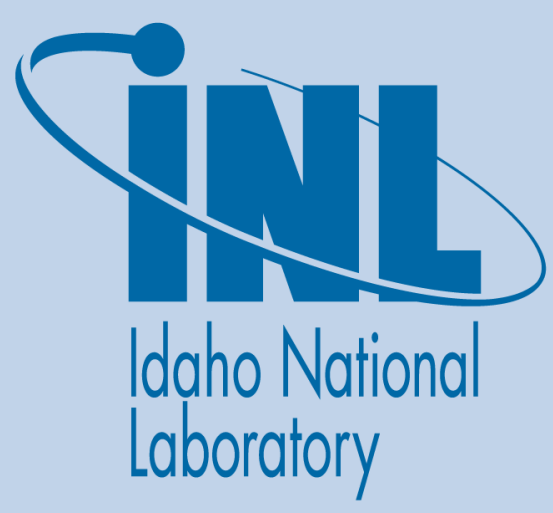

Jason M. Harp, Paul A. Demkowicz, John D. Stempien

January 2020 


\section{DISCLAIMER}

This information was prepared as an account of work sponsored by an agency of the U.S. Government. Neither the U.S. Government nor any agency thereof, nor any of their employees, makes any warranty, expressed or implied, or assumes any legal liability or responsibility for the accuracy, completeness, or usefulness, of any information, apparatus, product, or process disclosed, or represents that its use would not infringe privately owned rights. References herein to any specific commercial product, process, or service by trade name, trademark, manufacturer, or otherwise, does not necessarily constitute or imply its endorsement, recommendation, or favoring by the U.S. Government or any agency thereof. The views and opinions of authors expressed herein do not necessarily state or reflect those of the U.S. Government or any agency thereof. 
INL/EXT-16-39777

Revision 1

\title{
Fission Product Inventory and Burnup Evaluation by Gamma Spectrometry of the AGR-2 Irradiation
}

\author{
Jason M. Harp, Paul A. Demkowicz, John D. Stempien
}

January 2020

Idaho National Laboratory

INL ART Program

Idaho Falls, Idaho 83415

http://www.inl.gov

Prepared for the

U.S. Department of Energy

Office of Nuclear Energy

Under DOE Idaho Operations Office

Contract DE-AC07-05ID14517 
INL ART Program

\title{
Fission Product Inventory and Burnup Evaluation by Gamma Spectrometry of the AGR-2 Irradiation
}

\author{
INL/EXT-16-39777 \\ Revision 1 \\ January 2020
}

Reviewed by:
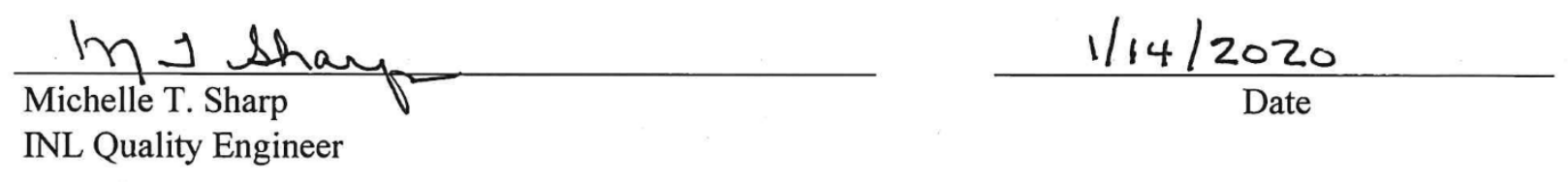

Approved by:

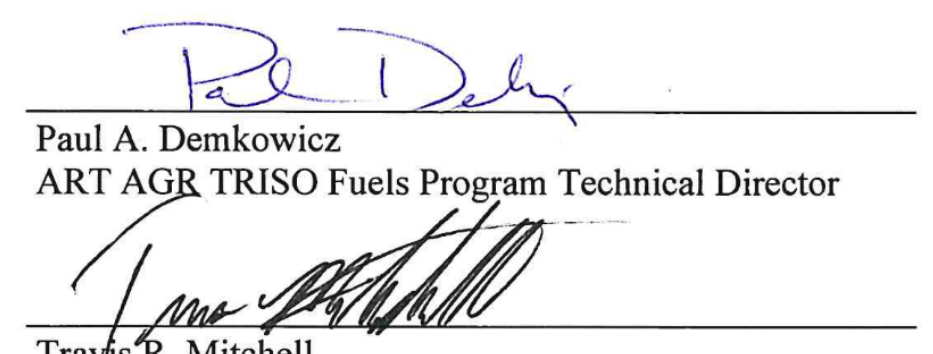

Travis R. Mitchell

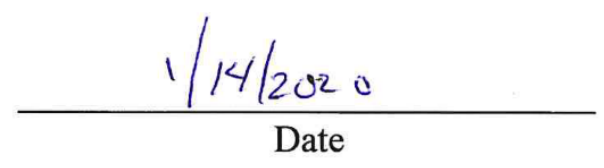

ART Program Manager

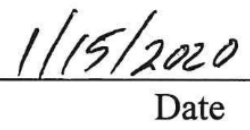




\section{REVISION LOG}

\begin{tabular}{|c|c|c|c|}
\hline Rev. & Date & Affected Pages & Revision Description \\
\hline 0 & 09/29/2019 & All & New document. \\
\hline 1 & $01 / 15 / 2020$ & vi, $1-9,13-21$ & $\begin{array}{l}\text { vi and 1-3: minor edits for clarity. p. 2: added reference } \\
\text { to AGR-2 mass balance report. p. 3: added time zone to } \\
\text { date referenced, added new Table } 1 \text { and description of } \\
\text { Table } 1 \text {. p. } 4 \text { : New Appendix A referenced in body of } \\
\text { text. pp. } 4-5 \text { : paragraphs reorganized and minor edits. p. } \\
\text { 6: Table } 2 \text { updated with } 4 \text { new columns tabulating } \\
\text { burnups derived from Cs-137 activity. Updated text } \\
\text { associated with Table } 2 \text {. p. } 7 \text { : Table } 3 \text { Capsule } 6 \\
\text { compacts Ag-110m values corrected. Also added two } \\
\text { references for destructive compact exams. p. } 8 \text {, Figure 5: } \\
\text { Capsule } 6 \text { Ag-110m values corrected. All compacts } \\
\text { temperature values (x-axis) corrected. pp. } 8 \text {-9 and } 13-14 \text { : } \\
\text { minor edits. p. } 14 \text { : Figure } 14 \text { updated with corrected } \\
\text { values for Capsule } 6 \text { compact inventories and updated } \\
\text { with correct values for Cap } 3 \text { and } 6 \text { compact holders. } \\
\text { Section describing work performed on Capsules } 1 \text { and } 4 \\
\text { moved up from Section } 5 \text { into Section } 4 \text {. Conclusions } \\
\text { moved to Section } 5 \text {. Conclusions re-ordered, and } \\
\text { additional statements added. pp. } 15-16 \text { : three references } \\
\text { added. pp. } 17-21 \text { : new Appendix A added. }\end{array}$ \\
\hline & & & \\
\hline & & & \\
\hline & & & \\
\hline & & & \\
\hline & & & \\
\hline & & & \\
\hline & & & \\
\hline & & & \\
\hline & & & \\
\hline & & & \\
\hline & & & \\
\hline & & & \\
\hline & & & \\
\hline & & & \\
\hline
\end{tabular}




\section{SUMMARY}

Gamma spectrometry has been used to evaluate the burnup and fission product inventory of different components from the U.S. Advanced Gas Reactor (AGR) Fuel Development and Qualification Program's second tristructural isotropic (TRISO)-coated particle fuel irradiation test (AGR-2). TRISO fuel in this irradiation included both uranium carbide/uranium oxide (UCO) kernels and uranium oxide $\left(\mathrm{UO}_{2}\right)$ kernels. Four of the 6 capsules contained fuel from the U.S. AGR program, and only those capsules will be discussed in this work. The inventories of gamma-emitting fission products from the fuel compacts and graphite compact holders were evaluated. These data were used to estimate the fractional release of fission products such as Cs-137, Cs-134, Eu-154, Ce-144, and $\mathrm{Ag}-110 \mathrm{~m}$ from the compacts. The fraction of $\mathrm{Ag}-110 \mathrm{~m}$ retained in the compacts ranged from approximately $2 \%$ of the calculated inventory to approximately full retention. Additionally, the activities of the radioactive cesium isotopes (Cs-134 and Cs-137) have been used to evaluate the burnup of all U.S. TRISO fuel compacts in the irradiation. The experimental burnup evaluations compare favorably with burnups calculated from physics simulations. Calculated burnups for UCO compacts range from 7.26 to $13.15 \%$ fissions per initial metal atom (FIMA) and 9.01 to $10.69 \%$ FIMA for $\mathrm{UO}_{2}$ compacts. Measured burnup ranged from 7.3 to $13.1 \%$ FIMA for UCO compacts and 8.5 to $10.6 \%$ FIMA for $\mathrm{UO}_{2}$ compacts. Results from gamma emission computed tomography performed on the graphite holders that reveal the distribution of different fission products in a component will also be discussed. Gamma tomography of graphite holders was also used to locate the position of compacts with TRISO fuel particles suspected of having silicon carbide layer failures that lead to in-pile cesium release. 


\section{ACKNOWLEDGMENTS}

This work was supported by the U.S. Department of Energy, Office of Nuclear Energy. Assistance with quantitative analysis of fission product inventories was provided by the INL Analytical Laboratory, and many hot cell activities were performed by staff of the INL Hot Fuel Examination Facility. 


\section{CONTENTS}

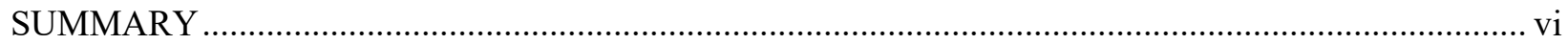

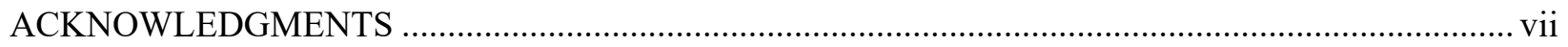

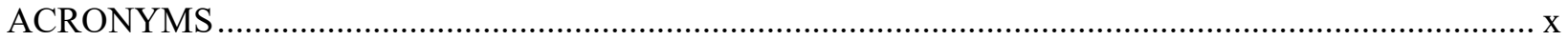

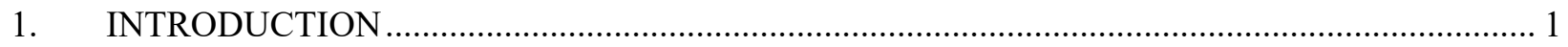

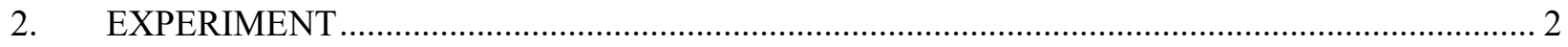

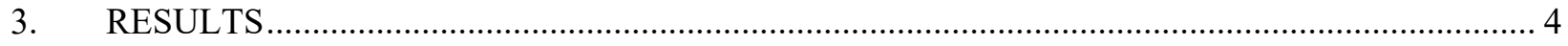

3.1 Compact Gamma Spectrometry Results ....................................................................... 4

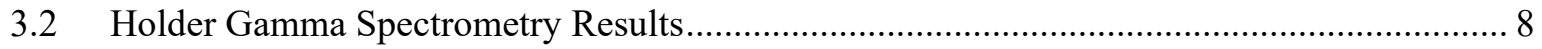

3.3 Total Holder Inventories Based on PGS Exams ................................................................ 13

3.4 Silver in Additional Capsule Components ....................................................................... 13

4. GAMMA SPECTROMETRY DATA FROM CAPSULE 1 AND CAPSULE 4 _....................... 14

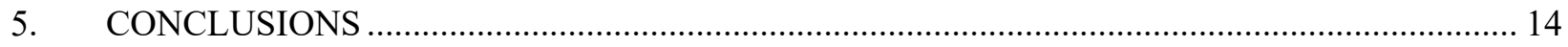

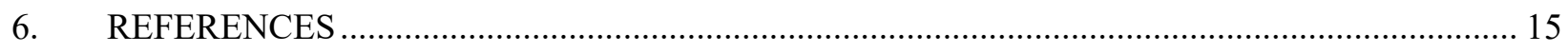

\section{FIGURES}

Figure 1. Major components of a representative AGR-2 capsule .......................................................... 2

Figure 2. Compact numbering scheme for AGR-2 Compacts. ................................................................... 2

Figure 3. Illustration of the off-axis PGS scanning of AGR-2 graphite holders......................................... 4

Figure 4. Burnup evaluation of AGR-2 based on gamma spectrometry of AGR-2 compacts and

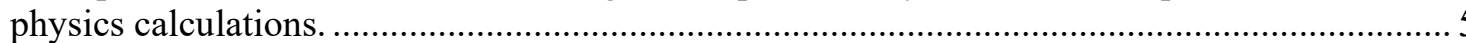

Figure 5. Decay-corrected, measured-to-calculated Ag-110m activity ratios for each U.S. AGR-2 capsule as a function of the TAVA irradiation temperatures calculated in [14] ......................... 8

Figure 6. Off-axis distribution of different fission products detected in left and right side axial scans of Holders 2 and 3 .

Figure 7. Cs-134 distribution in Holder 2 Level 2 (left) and Cs-137 distribution in Holder 2 Level 2 (right). 10

Figure 8. Eu-154 distribution in Holder 2 Level 2 ........................................................................... 10

Figure 9. Ag-110m distribution in Holder 3 Level 2 .......................................................................... 10

Figure 10. Off-axis distribution of different fission products detected in left and right side axial scans of Holder 5 .

Figure 11. Tomographic Cs-134 gamma scans from Levels 2 (left) and 3 (right) of AGR-2 Holder 5 . 
Figure 12. Off-axis distribution of Ag-110m detected in left and right side axial scans of

Holder 6

Figure 13. Tomographic Cs-134 gamma scans from Levels 2 (left) and 3 (right) of AGR-2 Holder 6. 12

Figure 14. Inventory of Ag-110m in different capsule components compared to the calculated inventory for each capsule.

\section{TABLES}

Table 1. Activity and activity ratio to burnup conversion coefficients. 3

Table 2. Burnup from physics calculations (\% FIMA) compared to measured burnup derived from the ratio of Cs-134 to Cs-137 (labeled as "134:137") and the measured burnup based on the detected Cs-137. The asterisk (*) in each compact ID number corresponds to the capsule number.

Table 3. Measured Ag-110m inventory as a percent of the calculated inventory for compacts from AGR-2 Capsules 2, 3, 5, and 6. The asterisk (*) in each compact ID number corresponds to the capsule number. Uncertainties are given in parentheses for each value. 7

Table 4. Total activity in MBq of fission products present in each graphite holder. .13

Table 5. Fraction of total inventory in each graphite holder. 


\section{ACRONYMS}

AGR Advanced Gas Reactor

CEA Commissariat à l'énergie atomique

HFEF Hot Fuel Examination Facility

HPGe high purity germanium

FIMA fissions of initial metal atoms

INL Idaho National Laboratory

PBMR Pebble Bed Modular Reactor Ltd.

PGS Precision Gamma Scanner

PIE post-irradiation examination

TAVA time-average, volume-average

TRISO tristructural isotropic

UCO heterogeneous mixture of uranium carbide/uranium oxide

$\mathrm{UO}_{2} \quad$ uranium oxide 


\section{Fission Product Inventory and Burnup Evaluation by Gamma Spectrometry of the AGR-2 Irradiation \\ 1. INTRODUCTION}

The Advanced Gas Reactor (AGR) program tristructural isotropic (TRISO) fuel irradiation known as AGR-2 was the second test in a series of irradiations designed to qualify UCO (a heterogeneous mixture of $\mathrm{UO}_{2}$ and uranium carbide) TRISO fuel for use in next generation reactors. The first irradiation, AGR-1, and its associated post-irradiation examination (PIE) and safety testing demonstrated the fuel performance of TRISO fuel produced on the laboratory scale [1],[2]. The AGR-2 irradiation and its associated PIE was designed to demonstrate the performance of fuel compacts fabricated using TRISO particles produced on an engineering scale [3],[4]. Additionally, while AGR-1 contained exclusively UCO TRISO kernels, AGR-2 contained a capsule with $\mathrm{UO}_{2}$ TRISO fuel to compare to AGR UCO performance [5].

The irradiation contained six separate capsules. Capsules 2, 3, 5, and 6 contained fuel fabricated in the U.S. and are the subject of this report. Capsules 2, 5, and 6 contained fuel compacts with UCO TRISO particles, while Capsule 3 contained compacts with $\mathrm{UO}_{2}$ particles. The AGR-2 UCO fuel consisted of nominally $425 \mu \mathrm{m}$ diameter kernels with $14.0 \%{ }^{235} \mathrm{U}$ enrichment. $\mathrm{UO}_{2}$ fuel consisted of nominally $500 \mu \mathrm{m}$ diameter fuel kernels with $9.6 \%{ }^{235} \mathrm{U}$ enrichment. The TRISO coatings on both types of kernels had nominal thicknesses of $100 \mu \mathrm{m}$ (buffer), $40 \mu \mathrm{m}$, (inner and outer pyrolytic carbon), and $35 \mu \mathrm{m}$ (SiC). The coated particles were formed into right cylindrical compacts approximately $12.3 \mathrm{~mm}$ in diameter and $25.1 \mathrm{~mm}$ in length. The particle packing fractions were $37 \%$ and $23 \%$ for the $\mathrm{UCO}$ and $\mathrm{UO}_{2}$ compacts, respectively [5].

Each of the six capsules was independently controlled for temperature and had dedicated sweep gas supply and monitoring for released fission gases [6],[7]. The major components of the AGR-2 capsules are shown in Figure 1 and include the fuel compacts, the graphite holder that supports the compacts, the graphite spacers, the capsule shell, and the gas exit lines. In each of the four AGR-2 capsules discussed in this work, there were 12 compacts arranged in three stacks of four compacts. The compact numbering scheme for AGR-2 is shown in Figure 2, where compacts are numbered by capsule number, axial level, and stack number. Compact 5-2-3, for example, would be the compact from Capsule 5, Level 2, and Stack 3 . 


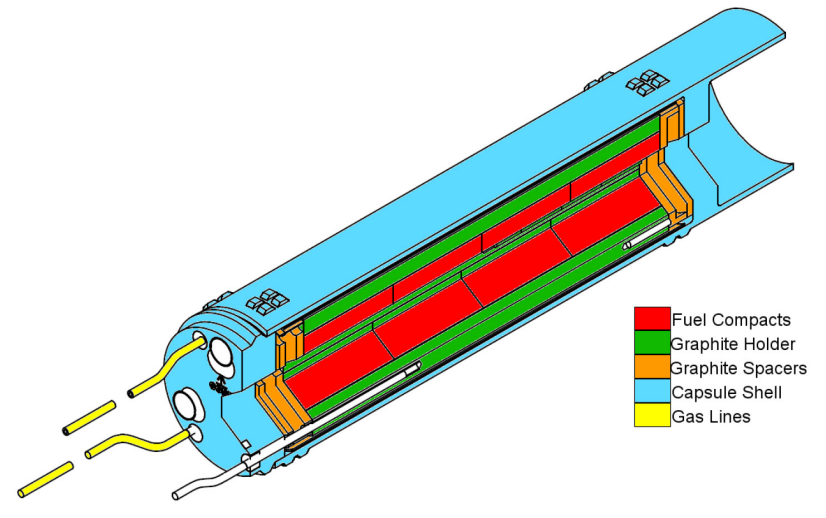

Figure 1. Major components of a representative AGR-2 capsule.

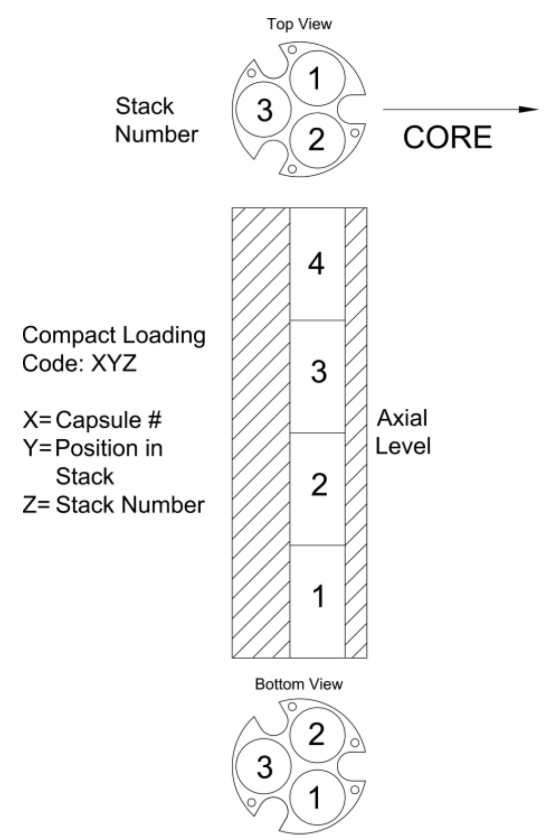

Figure 2. Compact numbering scheme for AGR-2 Compacts.

The AGR-2 irradiation was performed in the Idaho National Laboratory (INL) Advanced Test Reactor (ATR) for 12 cycles or 559.2 effective full power days. AGR-2 fuel reached calculated burnups ranging from 7.3 to $13.2 \%$ fissions per initial heavy-metal atom (FIMA) for UCO fuel and 9.0 to $10.7 \%$ FIMA for $\mathrm{UO}_{2}$ fuel. The time-averaged volume-averaged (TAVA) irradiation temperature for UCO fuel ranged from $987^{\circ} \mathrm{C}$ to $1296^{\circ} \mathrm{C}$, and for $\mathrm{UO}_{2}$ fuel the temperature ranged from $996^{\circ} \mathrm{C}$ to $1062^{\circ} \mathrm{C}$ [7].

Gamma spectrometry was used previously to evaluate the burnup of the AGR-1 TRISO fuel compacts [8]. Gamma spectrometry was also utilized to create an inventory of gamma-emitting fission products of each of the capsules in AGR-1 [9]. Additionally, gamma spectrometry of the graphite support structures in AGR-1 was able to identify compacts containing TRISO particles with failed SiC layers [10]. This combined experience from AGR-1 has been applied to the similar compacts and capsule components in AGR-2. This report focuses on gamma spectrometry results from the four U.S. fuel capsules. Results from this work have been used to construct the fission product mass balance for the AGR-2 experiment that indicates the release of fission products from the fuel compacts during irradiation [11].

\section{EXPERIMENT}

Gamma scanning was accomplished using the INL Hot Fuel Examination Facility (HFEF) Precision Gamma Scanner (PGS). PGS has three major components: the detector system, collimator, and stage. The detector system is a high purity germanium (HPGe) detector surrounded by a Compton suppression detector, and a digital multi-channel analyzer. The collimator is approximately $2.13 \mathrm{~m}$ long with an aperture that has a fixed width of $2.22 \mathrm{~cm}$ and a variable height of 0.254 to $0.00254 \mathrm{~cm}$. The collimator can also be rotated $90^{\circ}$ so that the fixed width of the aperture is vertical instead of horizontal. The stage suspends items before the collimator and moves them in a plane parallel to the face of the collimator. The stage can also rotate items about a central axis.

Compacts were suspended before the PGS collimator in a thin-walled aluminum tube and were individually encapsulated in an additional aluminum container. Calibration sources (Eu-152) packaged in equivalent containers and placed inside the same aluminum tube were scanned before the first compact 
and after the last compact to confirm the performance of the system. Each compact was typically scanned in $0.254 \mathrm{~cm}$ steps with the collimator height set to $0.254 \mathrm{~cm}$ for a live time of 30 minutes

The collected spectra were analyzed to evaluate the fission product content of each compact. Fission product inventories were decay-corrected to one day after the end of the AGR-2 irradiation (October 17, 2013 11:00 AM MST) and compared to the calculated fission product inventories from ECAR-2066 [12]. Burnup was calculated from both the measured Cs-137 activity and the measured Cs-134 to Cs-137 activity ratio and compared to the calculated compact-average burnup from ECAR-2066 [12]. Burnup determination follows the technique discussed in [8]. Table 1 lists the coefficients derived from this method that were then used to convert the total compact Cs-137 activity (in MBq) and the Cs-134 to Cs137 ratios into burnups. Burnup derived from solely from Cs-137 can only be calculated as an average for the entire compact, since the starting inventory of fissile material is not known for the thin section of the compact characterized in each scan. The total activity for a compact is determined by summing the local activity from all the different measurements of a single compact. The total is then converted to burnup. The burnup determined by the ratio of Cs-134 to Cs-137 can either be determined over the entire compact based on total activities or locally for every spectrum collected from each compact. This local measurement of burnup reveals significant burnup gradients in some compacts.

In addition to Cs-134 and Cs-137, the activity of several other gamma-emitting fission products present in the compacts was also quantified, including Zr-95, Ru-106, Ag-110m, Ce-144, and Eu-154. The quantification of Ag-110m was given special attention, and some additional longer scans were performed on specific compacts to better quantify the Ag-110m content. Because of a large number of spectra with no detectable Ag-110m in the initial scans, the Level 2 and 3 compacts from Capsule 5 were rescanned with longer scan times of 120 minutes.

Table 1 . Activity and activity ratio to burnup conversion coefficients.

\begin{tabular}{|c|c|c|c|c|}
\hline & \multicolumn{2}{|c|}{ Capsules 2, 5, and 6 } & \multicolumn{2}{c|}{ Capsule 3 } \\
\hline & $\begin{array}{c}\text { Cs-137 Activity } \\
(\mathrm{MBq})\end{array}$ & $\begin{array}{c}\text { Cs-134 / Cs-137 } \\
\text { Ratio }\end{array}$ & $\begin{array}{c}\text { Cs-137 Activity } \\
(\mathrm{MBq})\end{array}$ & $\begin{array}{c}\text { Cs-134 / Cs-137 } \\
\text { Ratio }\end{array}$ \\
\hline Slope & $9.91 \mathrm{E}-07$ & $9.04 \mathrm{E}+00$ & $1.32 \mathrm{E}-06$ & $8.75 \mathrm{E}+00$ \\
\hline Intercept & $5.97 \mathrm{E}-03$ & $2.40 \mathrm{E}+00$ & $-6.45 \mathrm{E}-01$ & $-3.36 \mathrm{E}-01$ \\
\hline
\end{tabular}

In addition to the compacts, the graphite holders were also gamma scanned with the PGS. The goal of these scans is to estimate the inventory and distribution of fission products in the graphite. The distribution of different fission products can be used to infer the fuel performance of compacts during irradiation, and information about fission product release from compacts can be gathered. Graphite holders were scanned in two ways. Initially, they were scanned in two off-axis sweeps to identify axial levels of interest and to estimate the total activity of different isotopes in the holders. In the off-axis scans, the half of the holder that contained Stack 2 and half of Stack 3 was typically scanned first, and the half of the holder that contained Stack 1 and the other half of Stack 3 was scanned second. During irradiation, Stacks 1 and 2 faced the center of the ATR core, and Stack 3 faced away from the center of the ATR core. See Figure 3 for an illustration of the off-axis scanning. If an axial level of interest was identified (for example, by an indication of elevated fission product activity), a tomographic scan of that level was performed, during which the PGS collimator was rotated to a vertical orientation and the holder was turned about its axial centerline after the PGS scans across the holder at a particular level and angle. The scans from several angles were used to reconstruct an activity intensity map of a particular isotope in the graphite holder. Image reconstruction utilizes Gamma Emission Computed Tomography (GECT) and produces isotope-specific tomograms as described in [13]. The axial levels of interest within the graphite 
holders were typically levels that contained Cs-134 and Cs-137 activity, which indicated that the compact from that location during the irradiation possibly had a TRISO particle with a failed SiC layer similar to what was seen in [10].

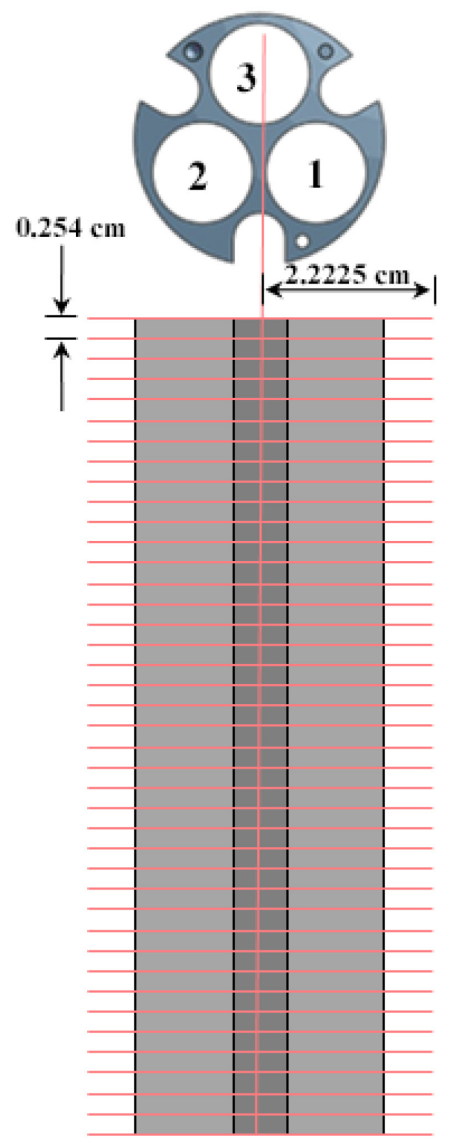

Figure 3. Illustration of the off-axis PGS scanning of AGR-2 graphite holders.

\section{RESULTS}

\subsection{Compact Gamma Spectrometry Results}

Data from the gamma spectrometry of compacts have been processed into burnup estimates and compared to the burnup from physics calculations [12]. The measured burnup values are the averages determined for each compact from the individual scan data. The burnups from physics calculations, the burnups derived from measured Cs- 134 to Cs-137 ratios, and the burnups derived from the Cs-137 measurements are plotted in Figure 4 as a function of the compact axial location in ATR for all U.S. capsules (i.e., 2, 3, 5, and 6). The same values are tabulated in Table 2. For select isotopes, measured activities and uncertainties are given in Appendix A for each AGR-2 compact.

Figure 4 plots burnup values in relation to the vertical displacement from ATR core centerline. There are 3 data points from each type of analysis at the same horizontal position on the graph because there are three compacts at each level, each in a different stack (see Figure 2). Because of the geometry of the capsule in the ATR core (where compacts in Stacks 1 and 2 faced the core, and Stack 3 compacts faced away from the core), the compacts in Stack 1 and 2 were irradiated with roughly equivalent neutron fluence, and the data from Stack 1 and Stack 2 reflect this in that they largely overlap. The compacts in Stack 3 were shielded from the core by the other stacks and saw a lower neutron fluence and thus a lower 
burnup. Local burnup can vary by 1 to $2 \%$ FIMA across a single compact, which is a statistically significant variation. Measured burnup ranged from 7.9 to $13.1 \%$ FIMA for UCO compacts and 8.5 to $10.6 \%$ FIMA for $\mathrm{UO}_{2}$ compacts. Overall, the burnups based on the ratio of Cs-134 to Cs-137 and the burnups based directly on the Cs-137 activity agree reasonably well with the calculated. This level of agreement is in line with AGR-1 [8]. Generally, the burnups derived from the Cs-134:Cs-137 are favored over the burnups derived solely from Cs- 137 because the ratios are less susceptible to biases introduced when determining the absolute efficiency of the detector system.

In the Capsule 5 data, there is significantly more scatter in the Stack 1 and Stack 2 Cs ratios than was typically seen in PGS scans of AGR-1 and in scans of the compacts from the other AGR-2 capsules. This is due to a statistically significant variability in the activity of Cs-137 and Cs-134 across the compacts from scan to scan, although the cause is unknown. The difference between measured and calculated burnup values in Stack 1 and Stack 2 (the higher-burnup stacks) in Capsule 6 is similar to what was seen in AGR-1 comparisons for Capsule 6, which was in a similar axial position relative to the ATR core [8].

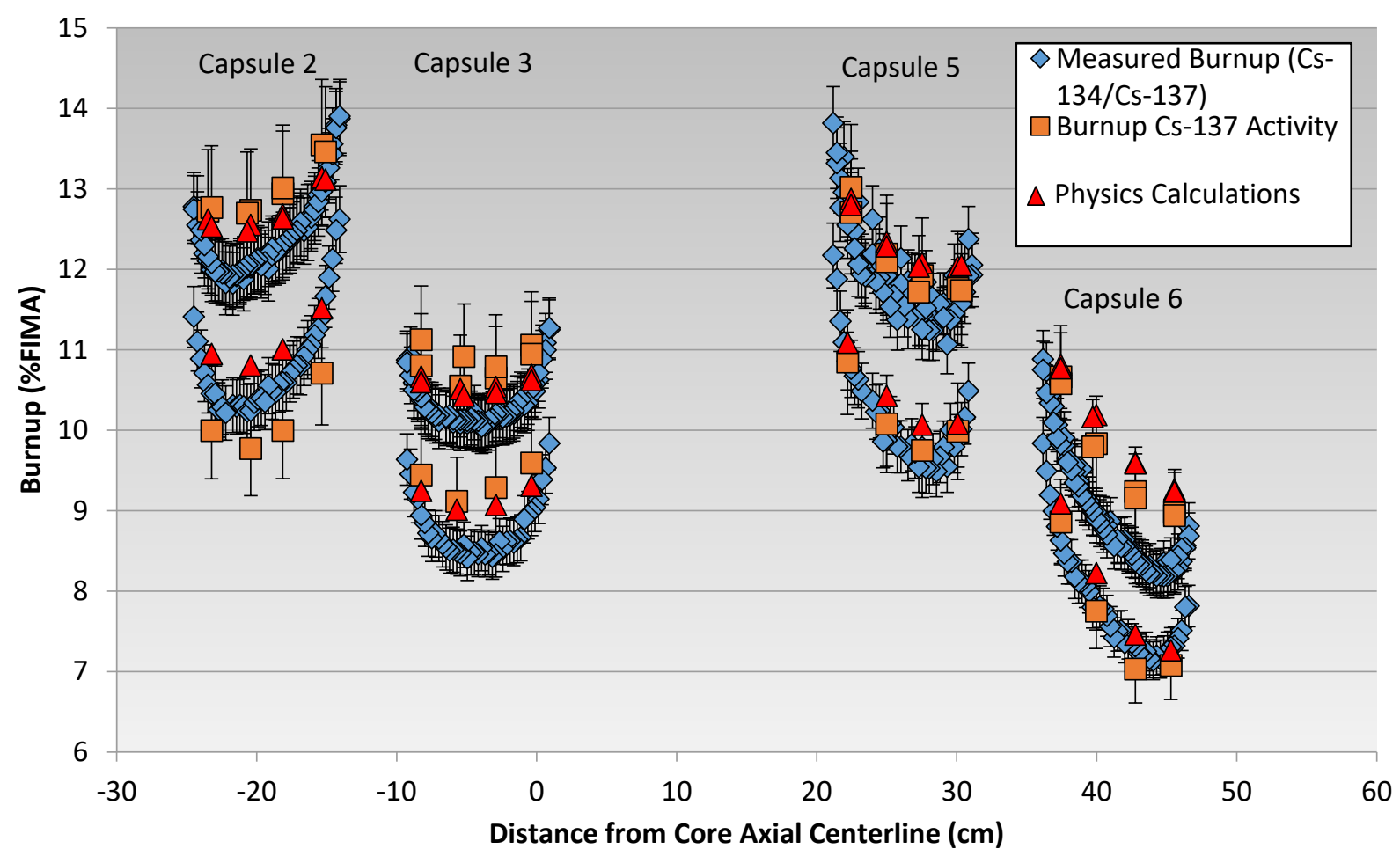

Figure 4. Burnup evaluation of AGR-2 based on gamma spectrometry of AGR-2 compacts and physics calculations. 
Table 2. Burnup from physics calculations (\% FIMA) compared to measured burnup derived from the ratio of Cs-134 to Cs-137 (labeled as "134:137") and the measured burnup based on the detected Cs-137. The asterisk $(*)$ in each compact ID number corresponds to the capsule number.

\begin{tabular}{|c|c|c|c|c|c|c|c|c|c|c|c|c|}
\hline \multirow[b]{2}{*}{ 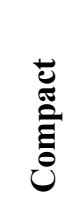 } & \multicolumn{3}{|c|}{ Capsule 2} & \multicolumn{3}{|c|}{ Capsule 3} & \multicolumn{3}{|c|}{ Capsule 5} & \multicolumn{3}{|c|}{ Capsule 6} \\
\hline & $\frac{\tilde{n}}{\vec{n}}$ & $\begin{array}{l}\hat{n} \\
\ddot{\dot{m}} \\
=\end{array}$ & $\frac{\hat{n}}{\dot{1}}$ & $\begin{array}{l}\frac{n}{0} \\
\frac{0}{n} \\
\frac{2}{2}\end{array}$ & $\underset{\stackrel{n}{\ddot{n}}}{\stackrel{n}{ت}}$ & $\frac{\hat{m}}{\dot{1}}$ & 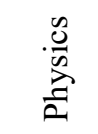 & $\begin{array}{l}\hat{m} \\
\ddot{\dot{m}} \\
\end{array}$ & $\frac{\hat{m}}{\dot{1}}$ & $\begin{array}{l}\frac{n}{0} \\
\frac{0}{n} \\
\frac{2}{2}\end{array}$ & $\begin{array}{c}\hat{n} \\
\ddot{\ddot{m}}\end{array}$ & $\begin{array}{l}\hat{m} \\
\dot{v} \\
\dot{v}\end{array}$ \\
\hline$*-4-3$ & 11.52 & 11.6 & 10.7 & 9.31 & 9.1 & 9.6 & 10.08 & 10.0 & 10.0 & 7.26 & 7.9 & 7.1 \\
\hline$*-3-3$ & 11.00 & 10.6 & 10.0 & 9.07 & 8.5 & 9.3 & 10.07 & 9.6 & 9.7 & 7.46 & 8.0 & 7.1 \\
\hline$*-2-3$ & 10.80 & 10.3 & 9.8 & 9.01 & 8.5 & 9.1 & 10.42 & 10.0 & 10.1 & 8.22 & 8.6 & 7.8 \\
\hline$*-1-3$ & 10.95 & 10.6 & 10.0 & 9.25 & 9.0 & 9.4 & 11.09 & 11.1 & 10.8 & 9.09 & 9.3 & 8.9 \\
\hline$*-4-2$ & 13.15 & 13.1 & 13.5 & 10.69 & 10.6 & 11.1 & 12.03 & 11.8 & 11.8 & 9.26 & 8.8 & 9.0 \\
\hline$*-3-2$ & 12.68 & 12.3 & 12.9 & 10.54 & 10.1 & 10.7 & 12.08 & 11.6 & 11.9 & 9.60 & 9.1 & 9.3 \\
\hline$*-2-2$ & 12.55 & 12.0 & 12.7 & 10.51 & 10.1 & 10.5 & 12.34 & 12.0 & 12.2 & 10.19 & 9.7 & 9.9 \\
\hline$*-1-2$ & 12.62 & 12.2 & 12.7 & 10.66 & 10.4 & 10.8 & 12.88 & 12.9 & 12.7 & 10.81 & 10.6 & 10.7 \\
\hline$*-4-1$ & 13.11 & 13.1 & 13.5 & 10.62 & 10.6 & 10.9 & 12.05 & 11.6 & 11.7 & 9.24 & 8.8 & 9.0 \\
\hline$*-3-1$ & 12.63 & 12.3 & 13.0 & 10.46 & 10.2 & 10.8 & 12.03 & 11.5 & 11.7 & 9.59 & 9.1 & 9.2 \\
\hline$*-2-1$ & 12.47 & 12.0 & 12.7 & 10.43 & 10.1 & 10.9 & 12.28 & 11.8 & 12.1 & 10.16 & 9.7 & 9.8 \\
\hline$*-1-1$ & 12.53 & 12.2 & 12.8 & 10.60 & 10.4 & 11.1 & 12.80 & 12.5 & 13.0 & 10.77 & 10.5 & 10.6 \\
\hline
\end{tabular}

In addition to burnup, another key metric for fuel performance and subsequent PIE is the percentage of $\mathrm{Ag}-110 \mathrm{~m}$ retained in each compact. This was estimated for each compact by dividing the decaycorrected measured Ag-110m inventory by the calculated inventory. The values are shown in Table 3 for the four U.S. capsules from AGR-2, expressed as a percentage of the calculated inventory that was measured in each compact. The calculated activity may be under-predicted in some compacts, resulting in a measured/calculated activity ratio greater than $100 \%$. The data in Table 3 indicate that some compacts experienced a significant amount of silver release, as the remaining inventories are extremely low. The time-average-volume-average temperatures have been calculated for each AGR-2 compact in ECAR2476 [14], and it is possible to relate Ag-110m release to these temperatures to some degree. Figure 5 shows the ratio of the measured-to-calculated $(\mathrm{M} / \mathrm{C}) \mathrm{Ag}-110 \mathrm{~m}$ ratios as a function of the TAVA irradiation temperatures for each compact in each U.S. capsule. Experience from AGR-1 and AGR-2 has shown that the release of $\mathrm{Ag}-110 \mathrm{~m}$ is related to temperature, the time a compact stays at elevated temperatures, and the amount of Ag-110m present in the compact while it is at temperature. The retention is then a multi-physics problem that is dependent on several time-varying phenomena (besides temperature) such as neutron flux, neutron fluence, and radionuclide inventory. On-average, above about $1100^{\circ} \mathrm{C}$, the compact $\mathrm{Ag}-110 \mathrm{~m} \mathrm{M} / \mathrm{C}$ (i.e., the approximate fraction of $\mathrm{Ag}-110 \mathrm{~m}$ retained in the compact) is about $20 \%$ in Figure 5. 
Table 3. Measured Ag-110m inventory as a percent of the calculated inventory for compacts from AGR-2 Capsules 2, 3, 5, and 6. The asterisk (*) in each compact ID number corresponds to the capsule number. Uncertainties are given in parentheses for each value.

\begin{tabular}{|c|c|c|c|c|}
\hline \multirow{2}{*}{ Compact } & \multicolumn{3}{|c|}{ Measured Ag-110m inventory as a percent of the calculated inventory } \\
\cline { 2 - 5 } & Capsule 2 & Capsule 3 & Capsule 5 & Capsule 6 \\
\hline$* \mathbf{4 3}$ & $5.7 \%(-0.7 \%,+2.9 \%)$ & $114.1 \%(-1.4 \%,+1.4 \%)$ & $63.0 \%(-2.3 \%,+2.4 \%)$ & $68.8 \%(-5.3 \%,+6.1 \%)$ \\
\hline$* 33$ & $25.4 \%(-1.2 \%,+1.2 \%)$ & $86.6 \%(-1.3 \%,+1.3 \%)$ & $23.3 \%(-1.0 \%,+1.9 \%)$ & $39.4 \%(-3.9 \%,+7.4 \%)$ \\
\hline$* \mathbf{2 3}$ & $30.1 \%(-1.1 \%,+1.2 \%)$ & $84.7 \%(-1.4 \%,+1.4 \%)$ & $17.0 \%(-1.3 \%,+2.3 \%)$ & $24.2 \%(-3.0 \%,+8.5 \%)$ \\
\hline$* \mathbf{1 3}$ & $35.2 \%(-1.3 \%,+1.4 \%)$ & $109.6 \%(-1.6 \%,+1.6 \%)$ & $80.7 \%(-2.4 \%,+2.4 \%)$ & $74.9 \%(-3.4 \%,+5.4 \%)$ \\
\hline$* \mathbf{4 2}$ & $0.9 \%(-0.4 \%,+4.8 \%)$ & $115.6 \%(-1.1 \%,+1.1 \%)$ & $50.6 \%(-1.6 \%,+4.2 \%)$ & $78.2 \%(-3.5 \%,+3.7 \%)$ \\
\hline$* 32$ & $6.8 \%(-0.8 \%,+4.0 \%)$ & $94.2 \%(-1.1 \%,+1.1 \%)$ & $1.8 \%(-0.5 \%,+4.0 \%)$ & $17.6 \%(-2.3 \%,+7.9 \%)$ \\
\hline$* \mathbf{2 2}$ & $12.7 \%(-1.0 \%,+3.0 \%)$ & $93.7 \%(-1.1 \%,+1.1 \%)$ & $21.8 \%(-1.1 \%,+3.0 \%)$ & $21.5 \%(-2.4 \%,+7.4 \%)$ \\
\hline$* \mathbf{1 2}$ & $19.8 \%(-1.1 \%,+3.4 \%)$ & $98.2 \%(-1.0 \%,+1.7 \%)$ & $62.8 \%(-2.0 \%,+3.7 \%)$ & $56.4 \%(-2.7 \%,+6.9 \%)$ \\
\hline$* \mathbf{4 1}$ & $0.8 \%(-0.3 \%,+4.7 \%)$ & $117.4 \%(-1.1 \%,+1.1 \%)$ & $85.7 \%(-2.1 \%,+2.1 \%)$ & $81.3 \%(-4.4 \%,+4.5 \%)$ \\
\hline$* 31$ & $16.0 \%(-1.1 \%,+1.7 \%)$ & $94.1 \%(-1.0 \%,+1.0 \%)$ & $21.0 \%(-0.9 \%,+1.0 \%)$ & $16.5 \%(-1.9 \%,+10.0 \%)$ \\
\hline$* \mathbf{2 1}$ & $12.2 \%(-1.1 \%,+3.1 \%)$ & $94.4 \%(-1.1 \%,+1.1 \%)$ & $33.7 \%(-0.9 \%,+0.9 \%)$ & $5.5 \%(-1.3 \%,+10.5 \%)$ \\
\hline$* \mathbf{1 1}$ & $20.1 \%(-0.9 \%,+4.1 \%)$ & $114.6 \%(-1.1 \%,+1.1 \%)$ & $93.7 \%(-1.8 \%,+1.8 \%)$ & $54.0 \%(-2.6 \%,+6.9 \%)$ \\
\hline
\end{tabular}

The uncertainty on the measured/calculated activity ratio is not symmetric. The lower uncertainty band is equal to the square root of the sum of the squares of the activity uncertainty for each scan with a detectable amount of Ag-110m present for all scans that correspond to a particular compact. The upper uncertainty band is also equal to the square root of the sum of the squares of the activity uncertainty for each scan; however, in the case of a scan with an undetectable amount of Ag-110m, the activity uncertainty is replaced with the minimum detectable activity. Thus, the upper uncertainty band is always larger than the lower uncertainty band. Typically, the Stack 1 and Stack 2 compacts that were irradiated at the same level (e.g., Compacts 6-4-1 and 6-4-2) are similar in the measured/calculated Ag-110m activity ratio, but this trend does not always hold true (e.g., Compacts 5-3-2 and 5-3-1). More investigation into why compacts that had very similar irradiation conditions, but very different Ag retention, is warranted. Destructive examination [15] and safety testing [16] are in progress on the AGR-2 compacts, and will provide additional information on silver retention. In addition, the silver retention of the fuel compacts has been compared to fuel performance models [17]. Additional destructive PIE and safety testing results have also been reported in [18] and [19]. 


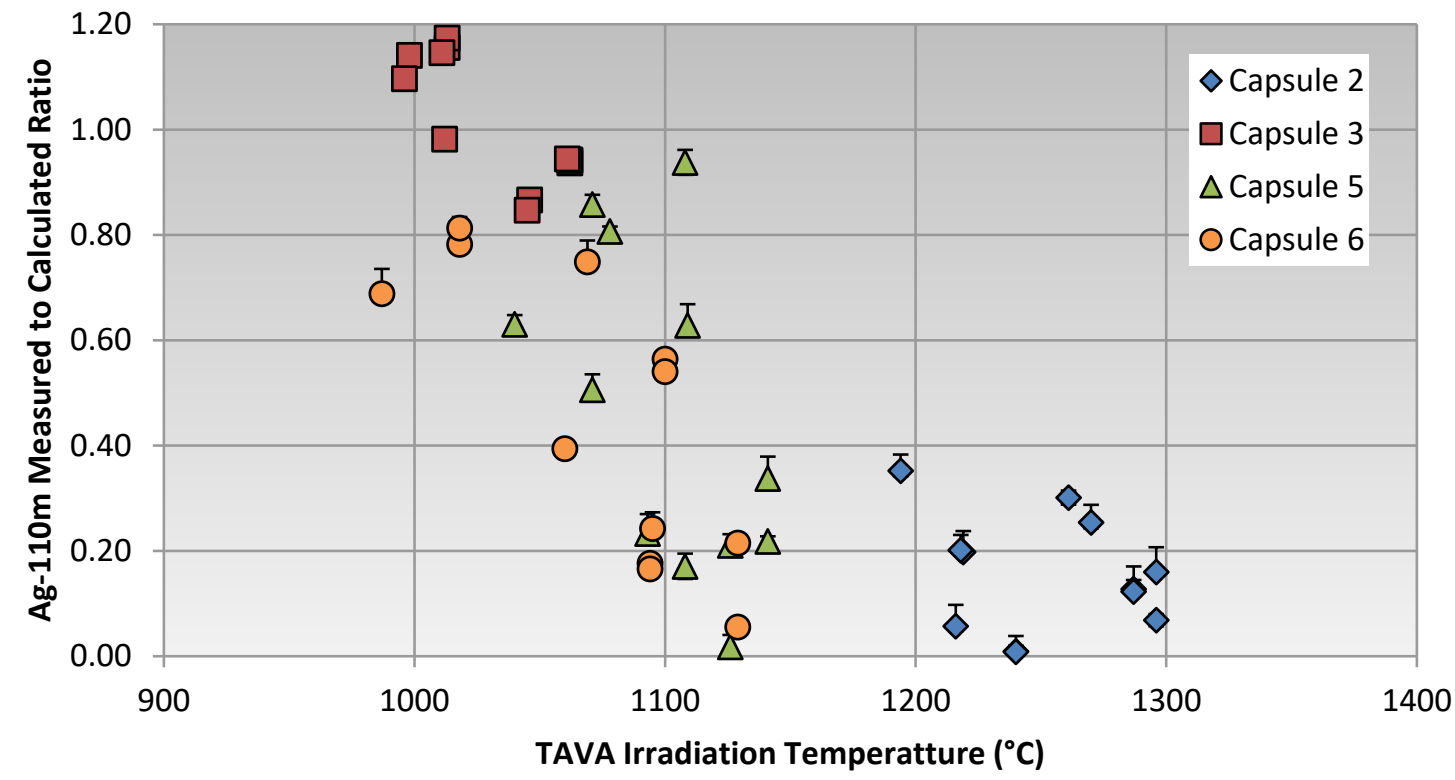

Figure 5. Decay-corrected, measured-to-calculated Ag-110m activity ratios for each U.S. AGR-2 capsule as a function of the TAVA irradiation temperatures calculated in [14].

\subsection{Holder Gamma Spectrometry Results}

The off-axis scans from the compact holders from Capsules 2 and 3 are shown in Figure 6 for several fission products. The scans are plotted so that the left side scan that contains Stack 2 and half of Stack 3 is shown on the left of the plot and the right side scan containing Stack 1 and the other half of Stack 3 is shown on the right of the plot. Holder 2 axial scans detected the presence of Ag-110m, Eu-154, Cs-134, and Cs-137 in the graphite. Most notably, the scans contained a consistently strong Cs-134 and Cs-137 signal isolated about Level 2 (location of the second level of compacts from the bottom, see Figure 2). Tomographic scans were able to identify that the cesium activity was predominantly located adjacent to the original location of Compact 2-2-3 in the graphite holder. The tomograms for Cs-134 and Cs-137 distribution at Level 2 of Holder 2 are shown in Figure 7. This suggests that this compact may have contained one or more particles that experienced $\mathrm{SiC}$ layer failure, releasing relatively high fractions of cesium isotopes. Subsequent PIE showed that there were several TRISO particles that experienced SiC layer failure in AGR-2 Compact 2-2-3 [15], as well as one particle that had an as-fabricated exposed kernel defect. Capsule 2 was operated at relatively high temperatures (average TAVA temperature for all compacts in the capsule was $1252^{\circ} \mathrm{C}$ ) [14], which likely contributed to the release of Eu-154 into the holder. Eu-154 was not measurable by gamma scanning any of the AGR-1 capsule holders, which were not operated at such high temperatures for long durations. Figure 6 and Figure 8 indicate that Eu-154 released locally to the graphite but did not migrate significantly. Thermal analysis indicates that the location of the highest Eu-154 activity in the Capsule 2 holder is also the approximate location of the hottest fuel temperatures within that capsule [14].

The only significant fission product present in Holder 3 was Ag-110m, and it was only present at Levels 2 and 3 of the holder (see Figure 6). This is consistent with Capsule $3 \mathrm{UO}_{2}$ compact measurements, which indicated lower $\mathrm{Ag}-110 \mathrm{~m} \mathrm{M} / \mathrm{C}$ ratios (indicating that $\mathrm{Ag}-110 \mathrm{~m}$ release occurred) from the Level 2 and 3 compacts for all three stacks. Tomograms of Holder 3 Level 2 indicate Ag-110m is distributed locally near the compacts in the cooler regions of the graphite holders near each stack as 
seen in Figure 9. Holder 3 contained no detectable Cs-134 or Cs-137, indicating TRISO particles with a failed $\mathrm{SiC}$ layer were unlikely to be present in this capsule.

Off-axis scans of Capsule 5 indicated large amounts of Ag-110m at Levels 2 and 3 in the holder (Figure 10). Small amounts of Cs-137 and Cs-134 were also located at Levels 2 and 3 of the holder. No other fission products were detected in the graphite holder. The Cs spikes centered around Levels 2 and 3 indicate that there may be one or more TRISO particles with a failed $\mathrm{SiC}$ layer in at least one of the compacts at these levels. Gamma tomography was performed on both of these levels. The Cs-134 tomograms from this analysis are shown in Figure 11. These images indicate that the Cs activity is adjacent to the compact in Stack 3 at both levels, suggesting the possibility that Compact 5-2-3 and/or Compact 5-3-3 may contain TRISO particles with failed SiC layers. Destructive exams of Compact 5-2-3 at Oak Ridge National Laboratory indicated that potentially 2 particles with failed SiC layers may have existed in the compact [18],[19]. Destructive exams of Compact 5-3-3 indicated one particle with an exposed kernel [19].

Off-axis scans of AGR-2 Holder 6 were also performed. In the case of Holder 6, elevated levels of Ag-110m were detected at the axial ends of the holder (Figure 12). This is similar to what was seen in Holder 1 and Holder 6 in AGR-1 [9]. Radioactive Cs isotopes were found at very low levels at Levels 2 and 3 of the holder and are also included in Figure 12. Tomographic scans that split Levels 2 and 3 of Holder 6 again indicate Cs release from Stack 3 (see Figure 13). The data suggest that Compact 6-2-3 and/or Compact 6-3-3 may contain particles with failed SiC layers. Destructive exams indicated one, possibly two, particles in Compact 6-2-3 with failed TRISO coatings [19]. No failed SiC layers or failed TRISO coatings were evident from destructive exams of Compact 6-3-3 [19].

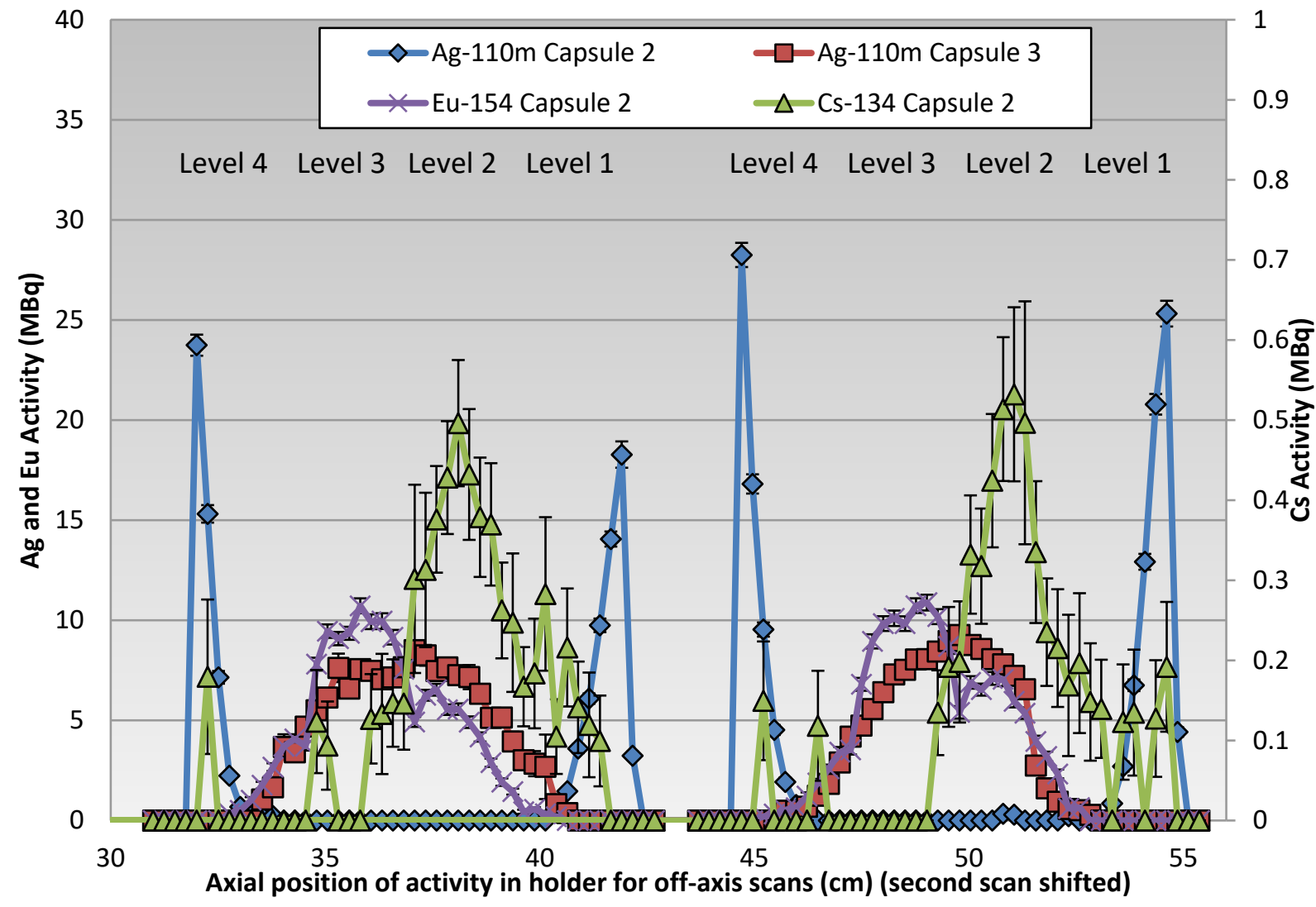

Figure 6. Off-axis distribution of different fission products detected in left and right side axial scans of Holders 2 and 3. 

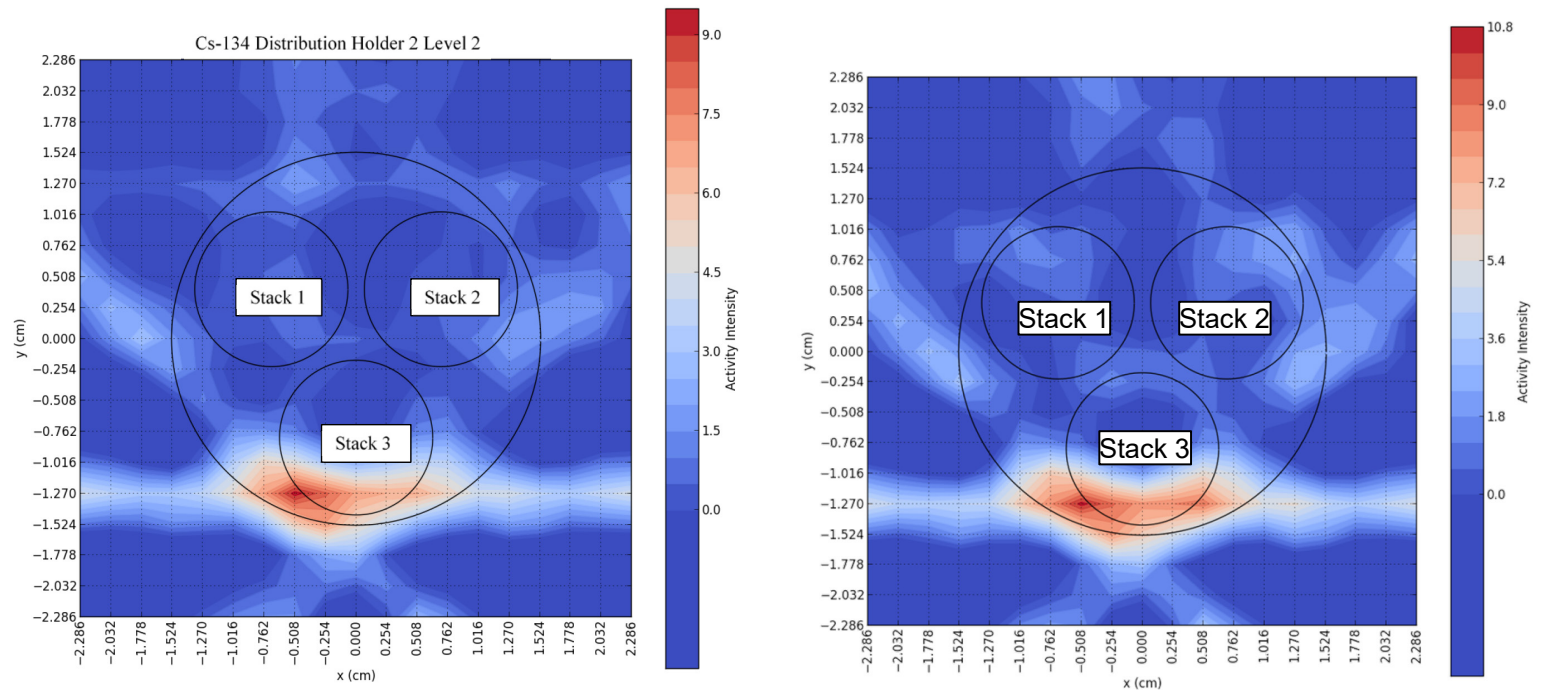

Figure 7. Cs-134 distribution in Holder 2 Level 2 (left) and Cs-137 distribution in Holder 2 Level 2 (right).

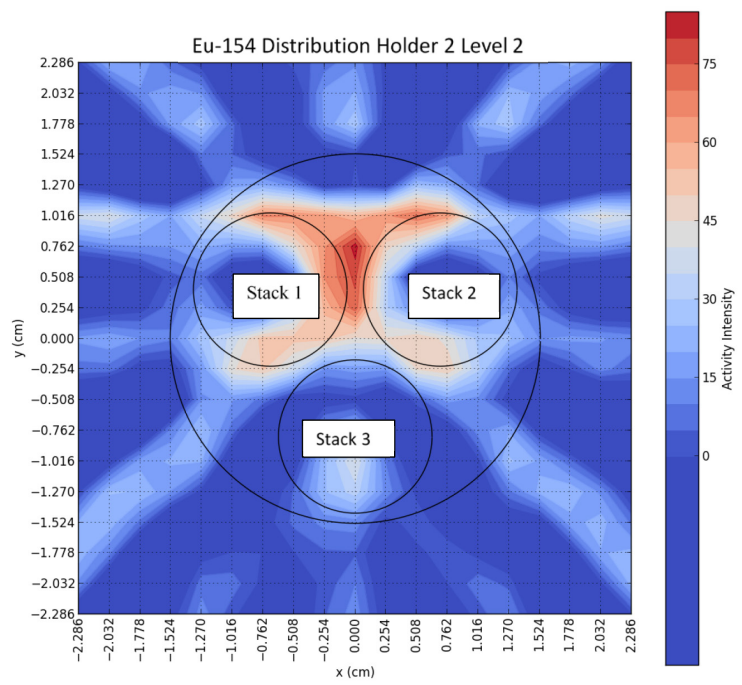

Figure 8. Eu-154 distribution in Holder 2 Level 2. Figure 9. Ag-110m distribution in Holder 3 Level 2. 


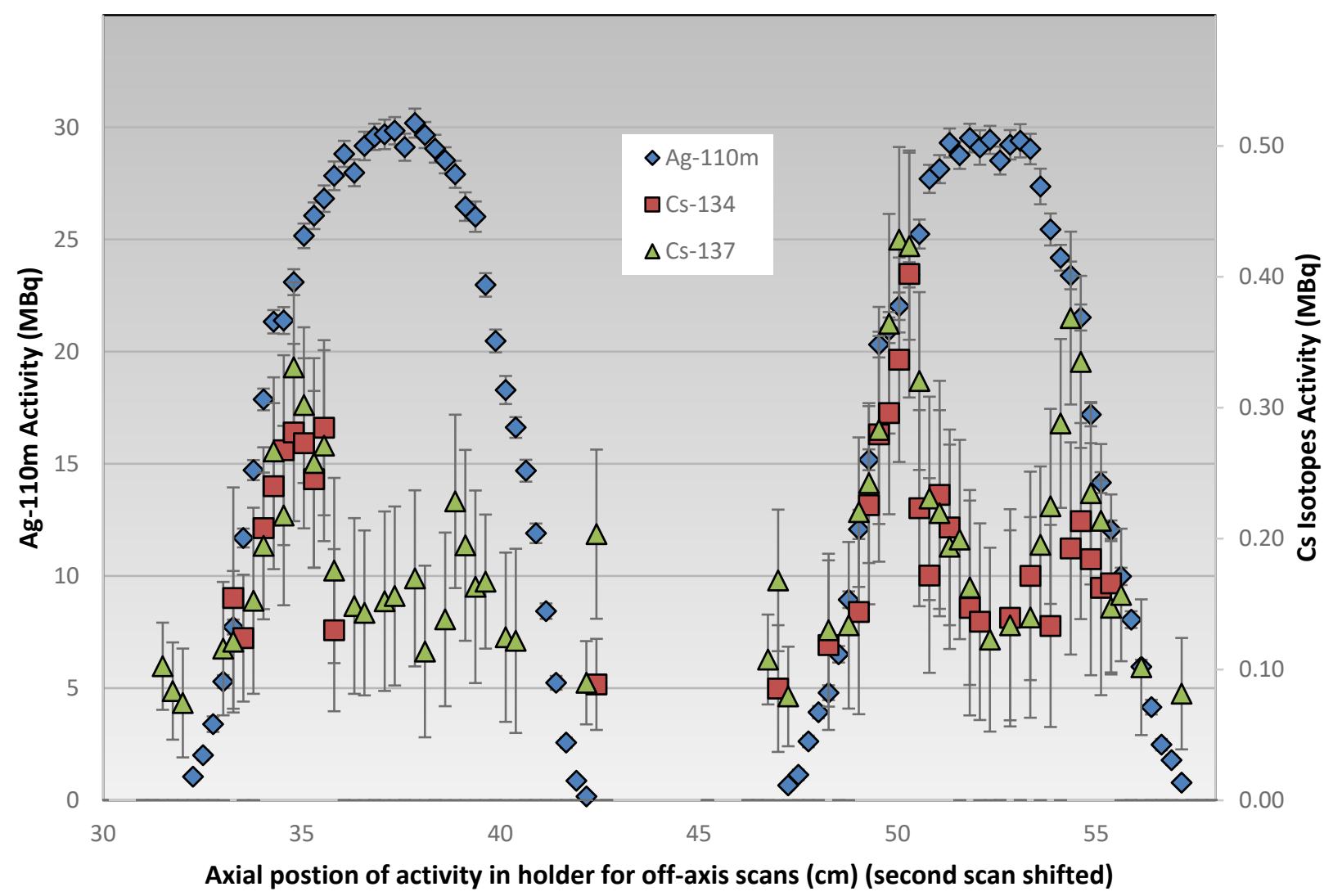

Figure 10. Off-axis distribution of different fission products detected in left and right side axial scans of Holder 5.
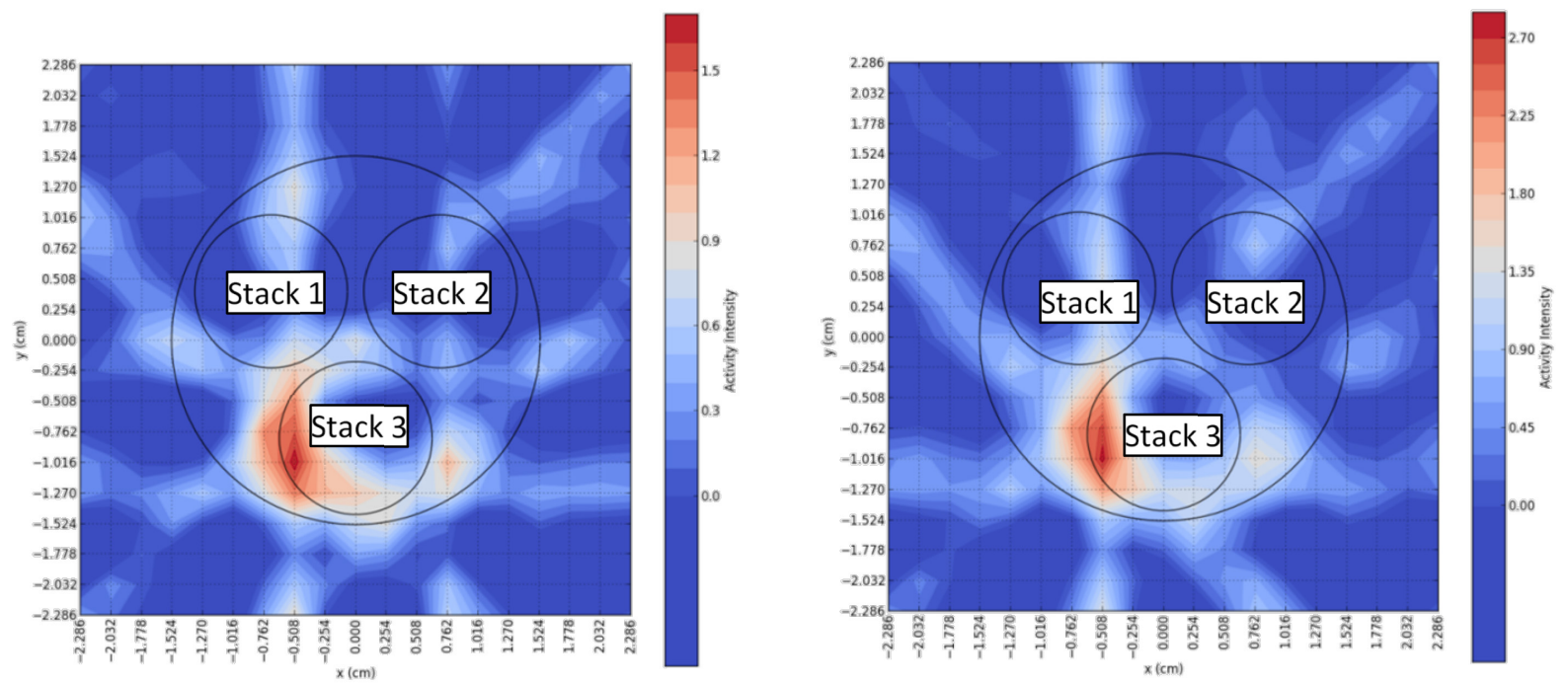

Figure 11. Tomographic Cs-134 gamma scans from Levels 2 (left) and 3 (right) of AGR-2 Holder 5. 


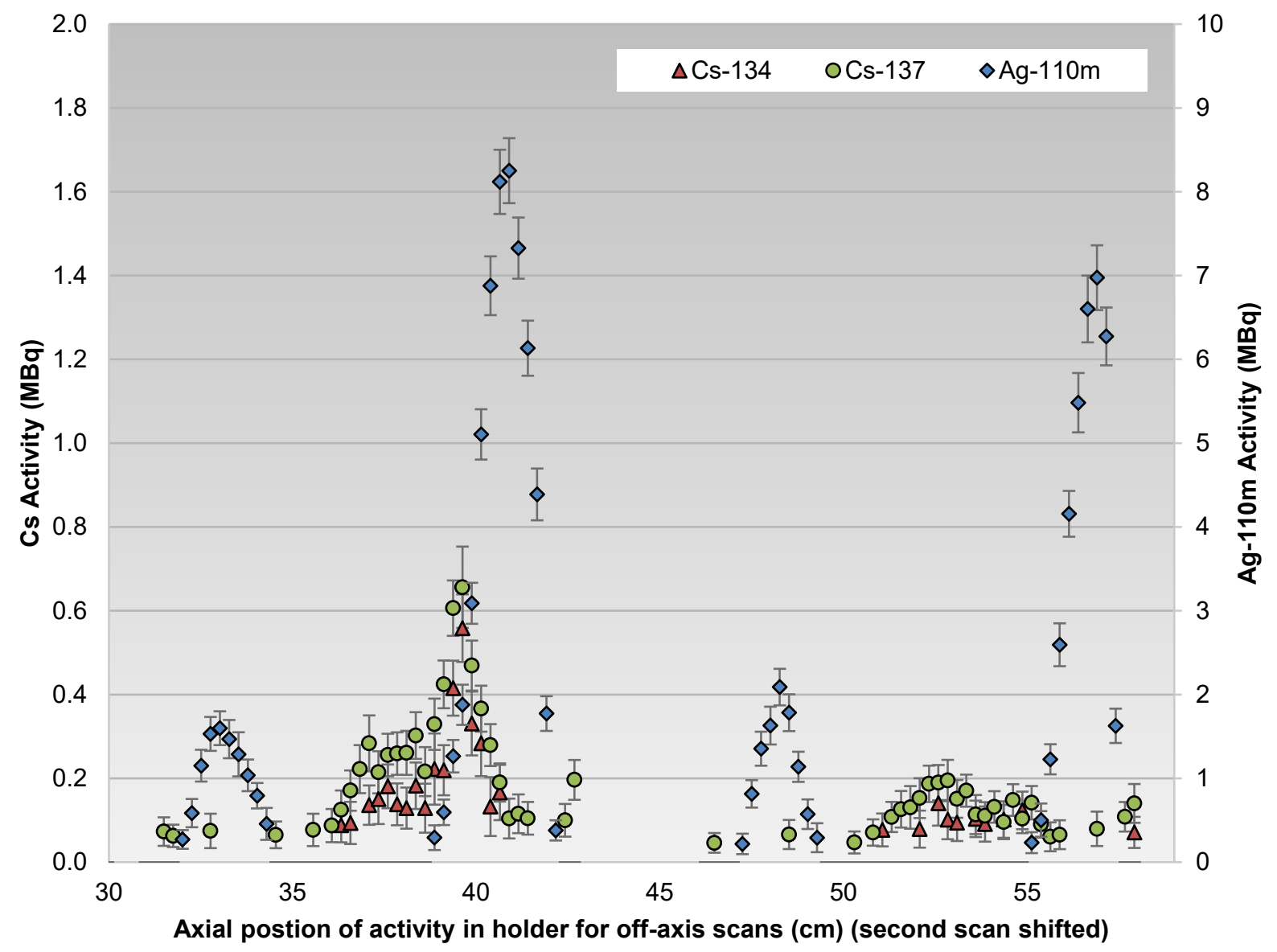

Figure 12. Off-axis distribution of Ag-110m detected in left and right side axial scans of Holder 6.
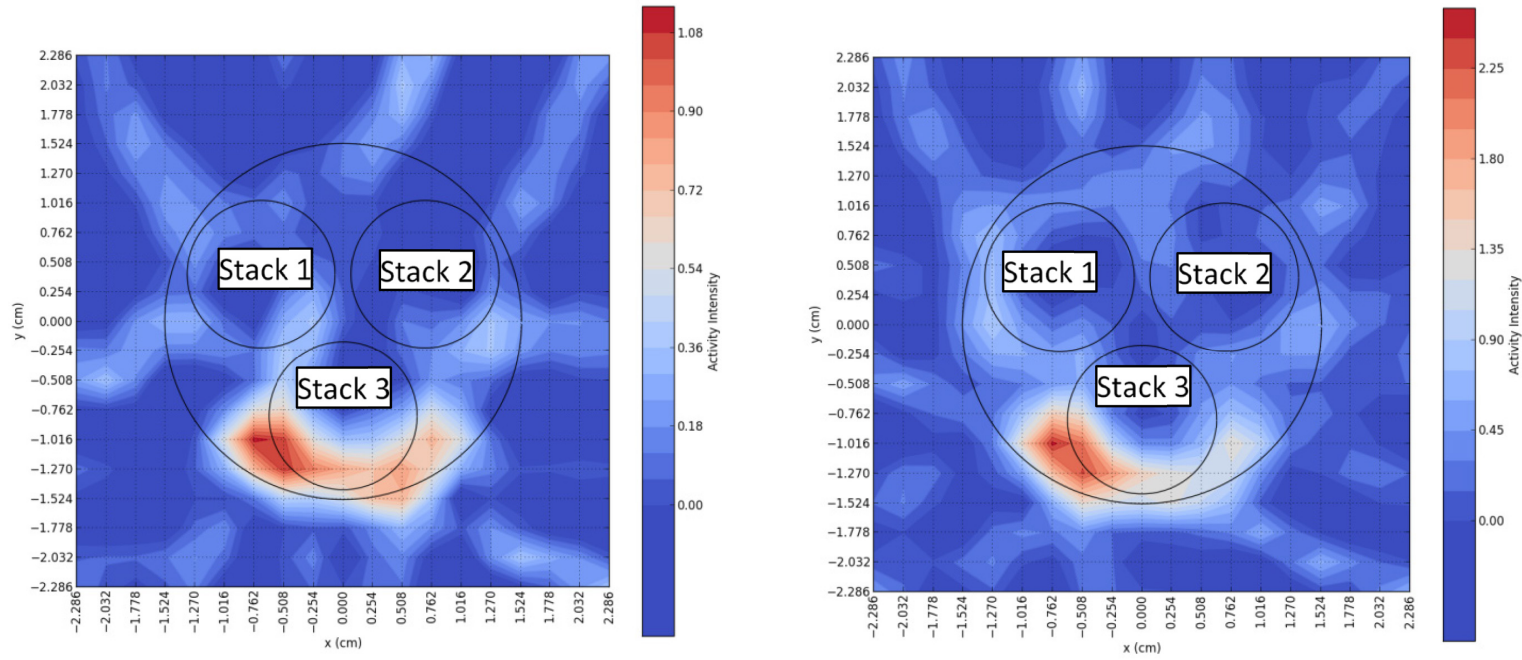

Figure 13. Tomographic Cs-134 gamma scans from Levels 2 (left) and 3 (right) of AGR-2 Holder 6. 


\subsection{Total Holder Inventories Based on PGS Exams}

It is possible to estimate the inventory of gamma-emitting fission products in the graphite holders by summing the measured activity from each scan taken during the off-axis scans of the holders. The total activity from the off-axis scans is shown in Table 4 for the fission products that were detected in the holders. The confidence intervals for these activities are shown in parentheses next to the activities. The lower confidence interval is equal to the square root of the sum of the squares of the activity uncertainties from counting statistics. The upper bound is equal to the square root of the sum of the squares of the activity uncertainties for each scan. The uncertainty was determined from counting statistics for scans with detectable activity, and if no activity was detected the minimum detectable activity was taken to be the uncertainty for that spectrum. Thus, the upper uncertainty on an activity is always larger than the lower uncertainty. If no activity was detected, the square root of the sum of the squares of the minimum detectable activities in each scan was taken as the minimum detectable activity for the entire holder. This was the case for Cs-134 and Eu-154 in Holder 3 and Eu-154 in Holder 6. The detected activities for Cs-137 in Holder 3 and Eu-154 in Holder 5 are due to inconsistent detectable activity signals over several consecutive scans and may be spurious signals as indicated by their large uncertainties. Spurious signals may be caused by the peak fitting software forcing a peak fit in background counts. All the other signals are consistent over several scans and indicate areas of fission products present in the holder. The corresponding fraction of inventory released to the graphite holder for a specific isotope is shown in Table 5. If no activity was detected, the minimum detectable activity for the entire holder was used to calculate the upper bound for fractional release to the holder. These values have been incorporated into the overall AGR-2 experiment fission product mass balance that estimates the total release of fission products from the AGR-2 fuel compacts during irradiation [11].

Table 4. Total activity in MBq of fission products present in each graphite holder.

\begin{tabular}{|l|c|c|c|c|}
\hline & Ag-110m (MBq) & Cs-134 (MBq) & Cs-137 (MBq) & Eu-154 (MBq) \\
\hline Holder 2 & $243.6(-1.0,+2.3)$ & $11.3(-0.3,+0.7)$ & $17.8(-0.3,+0.5)$ & $301.9(-1.1,+1.4)$ \\
\hline Holder 3 & $293.6(-1.6,+3.6)$ & $<2.3$ & $0.3(-0.1,+1.6)$ & $<2.1$ \\
\hline Holder 5 & $1444.1(-2.1,+2.4)$ & $6.7(-0.3,+0.9)$ & $11.6(-0.3,+0.4)$ & $0.2(-0.1,+1.6)$ \\
\hline Holder 6 & $111.2(-0.8,+2.3)$ & $4.5(-0.2,+0.7)$ & $9.7(-0.2,+0.4)$ & $<1.1$ \\
\hline
\end{tabular}

Table 5. Fraction of total inventory in each graphite holder.

\begin{tabular}{|l|c|c|c|c|}
\hline & Ag-110m & Cs-134 & Cs-137 & Eu-154 \\
\hline Holder 2 & $1.1 \mathrm{E}-1$ & $5.1 \mathrm{E}-5$ & $8.8 \mathrm{E}-5$ & $3.7 \mathrm{E}-2$ \\
\hline Holder 3 & $1.3 \mathrm{E}-1$ & $<1 \mathrm{E}-5$ & $2.6 \mathrm{E}-6$ & $<3 \mathrm{E}-4$ \\
\hline Holder 5 & $7.0 \mathrm{E}-1$ & $3.3 \mathrm{E}-5$ & $6.0 \mathrm{E}-5$ & $2.0 \mathrm{E}-5$ \\
\hline Holder 6 & $1.1 \mathrm{E}-1$ & $3.9 \mathrm{E}-5$ & $6.3 \mathrm{E}-5$ & $<2 \mathrm{E}-4$ \\
\hline
\end{tabular}

\subsection{Silver in Additional Capsule Components}

In addition to scanning with PGS, capsule components were sent to the hot cells at the Analytical Laboratory at the INL Materials and Fuels Complex for quantitative gamma spectrometry analysis of fission product inventories [11]. The graphite spacers were gamma counted on an out-of-cell HPGe detector. The capsule shells were leached, and the leachate for each capsule shell was analyzed for gamma-emitting fission products and Sr-90. Because negligible fission product activity was found in gas exit lines in AGR-1, the exit lines were not evaluated in the AGR-2 analysis.

The amount of decay-corrected Ag-110m detected in the compacts and in each capsule component was combined and compared to the value calculated from physics simulations to create a total Ag- $110 \mathrm{~m}$ 
mass balance for each capsule, shown in Figure 14. The apparent over-recovery of Ag-110m in Capsule 5 and Capsule 3 are likely due to under-prediction of the amount of Ag-110m in those capsules. A portion of the under-recovery of Ag-110m in Capsules 2 and 6 may be due to an over-prediction of the burnup in these capsules (especially Capsule 6, as shown in Figure 4) in addition to potential losses during chemical processing of the capsule components. This is especially true when large portions of the Ag-110m are found on the capsule hardware or capsule shells, such that a larger fraction of the total Ag-110m measurement may be subject to a bias due to incomplete recovery. Overall this agreement is acceptable and similar to what was seen in AGR-1. In AGR-1, the Ag-110m inventory balance for capsules with large amounts of Ag-110m on the capsule hardware was lower than when more was retained in the holders and the compacts [9].

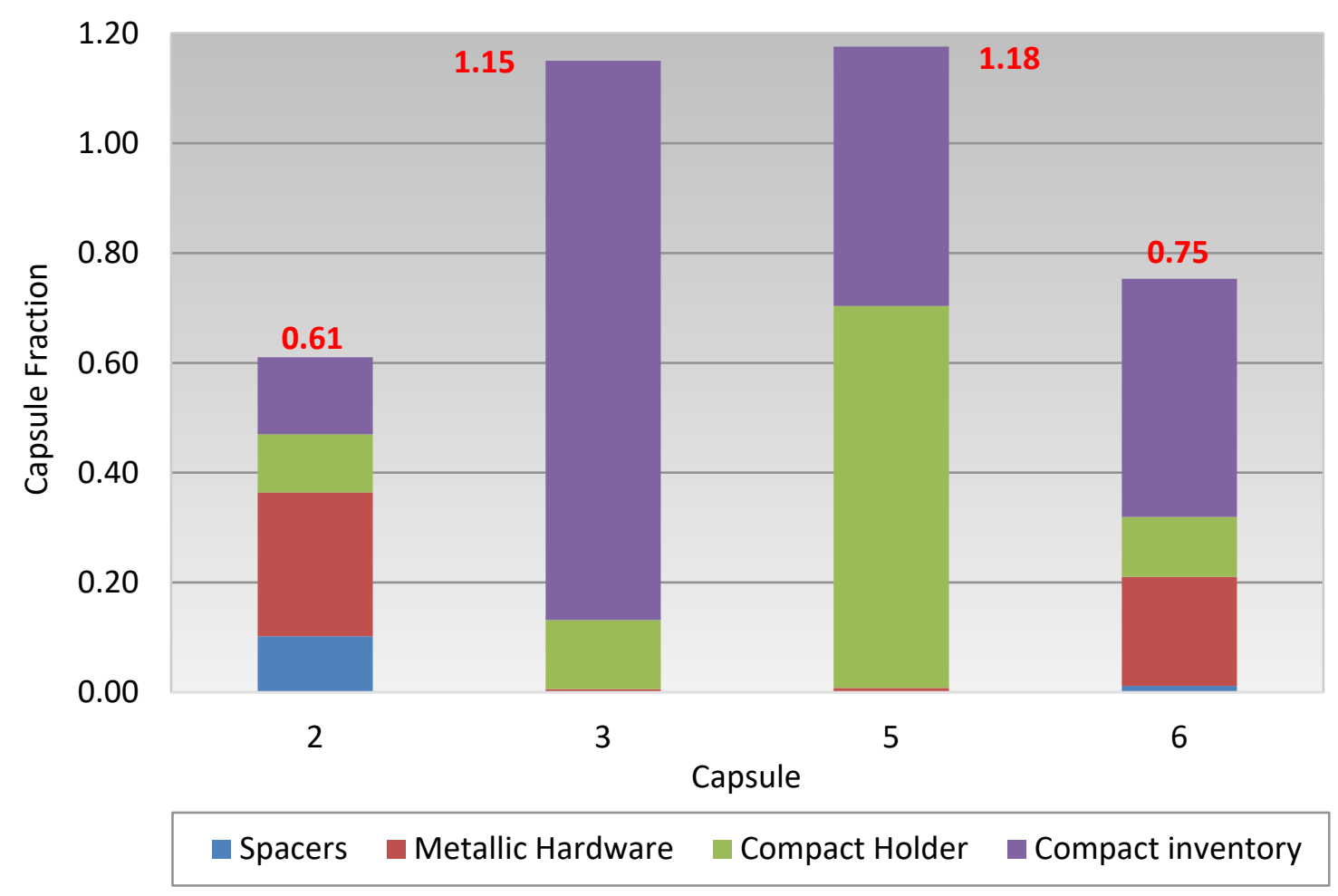

Figure 14. Inventory of Ag-110m in different capsule components compared to the calculated inventory for each capsule.

\section{GAMMA SPECTROMETRY DATA FROM CAPSULE 1 AND CAPSULE 4}

Gamma spectrometry was also performed on Capsule 1 and Capsule 4 from AGR-2. The data from Capsule 1 which contained TRISO fuel compacts from Commissariat à l'énergie atomique (CEA) is documented in INL/LTD-16-39736 [20]. The data from Capsule 4 which contained TRISO fuel compacts from Pebble Bed Modular Reactor Ltd. (PBMR) is documented in INL/LTD-16-39729 [21].

\section{CONCLUSIONS}

Gamma spectrometry scans of the U.S. capsules from AGR-2 have been completed. The gamma-emitting fission product inventory of each compact has been determined and compared to simulations of the irradiation test. The burnup of each compact from AGR-2 has been estimated using 
gamma spectrometry on both a whole-compact level by the direct Cs-137 inventory and axially along the compact length by the Cs-134 to Cs-137 ratio. The experimentally-measured burnup agrees well, within $0.7 \%$ FIMA for capsule average values, with the calculated burnup.

The retention of Ag-110m in the compacts was also estimated based on the measured inventory remaining in the compacts and the calculated inventory generated during the irradiation. The release of Ag- $110 \mathrm{~m}$ is a complex multi-physics phenomenon and this measurement will provide additional information to help evaluate the modeling of Ag-110m release. The inventory of Ag-110m in other capsule components was also evaluated and compared against the calculated inventory. These results show that a majority of the Ag-110m generated in the test has been accounted for in the experimental measurements. The retained fraction of Ag-110m from these measurements also helps to guide which compacts are chosen for further PIE such as destructive exams and safety testing that can provide additional data on the mechanisms of Ag-110m release.

The fission product distribution and inventory in the graphite holders was also examined. Axial scans determined the total fission product inventory in the graphite holders and the axial distribution of that inventory. Tomographic scans of the graphite holders over multiple angles were performed at specific axial locations of elevated fission product activity (namely Cs-134 and/or Cs-137). The data obtained from the axial and tomographic scans enabled location of compacts containing TRISO particles that were potentially defective or failed. In separate work, those compacts were then targeted for as-irradiated destructive exams that confirmed or denied the existence of defective particles or coatings in those compacts.

\section{REFERENCES}

[1] Demkowicz, P.A., Hunn, J.D., Ploger, S.A., Morris, R.N., Baldwin, C.A., Harp, J.M., Winston, P.L., Gerczak, T.J., Van Rooyen, I.J., Montgomery, F.C., Silva, C.M., 2016, "Irradiation performance of AGR-1 high temperature reactor fuel," Nuclear Engineering and Design, Vol. 306, pp. 2-13.

[2] Morris, R.N., Baldwin, C.A., Demkowicz, P.A., Hunn, J.D., and Reber, E.L., 2014, "Performance of AGR-1 high temperature reactor fuel during post irradiation heating tests," Proceedings of the $7^{\text {th }}$ International Topical Meeting on High Temperature Reactor Technology (HTR-2014), Weihai, China, October 27-31, 2014, Paper HTR2014-31135.

[3] Demkowicz, P.A., 2019, Technical Program Plan for INL Advanced Reactor Technologies Advanced Gas Reactor Fuel Development and Qualification Program, Idaho National Laboratory, PLN-3636, Rev. 8, June 2019.

[4] Petti, D.A., Maki, J., Hunn, J.D., Pappano, P., Barnes, C., Saurwein, J., Nagley, S., Kendall, J. and Hobbins, R., 2010, "Overview and Status of the DOE Advanced Gas Reactor (AGR) Fuel Development and Qualification Program," The Journal of The Minerals, Metals \& Materials Society, September 2010, p. 62-66.

[5] Collin, B.P., 2011, AGR-2 Irradiation Experiment Test Plan, Idaho National Laboratory, PLN3798 Rev. 1, October 2011.

[6] Grover, S.B., Petti, D.A., 2014, "Status of the NGNP fuel experiment AGR-2 irradiated in the advanced test reactor," Nuclear Engineering and Design, Vol. 271, pp. 238-243.

[7] Collin, B.P., 2018, AGR-2 Irradiation Test Final As-Run Report, Idaho National Laboratory, INL/EXT-14-32277, Rev. 4, February 2018.

[8] Harp, J. M., Demkowicz, P. A., Winston, P. L., and Sterbentz, J. W., 2014, “An analysis of nuclear fuel burnup in the AGR-1 TRISO fuel experiment using gamma spectrometry, mass spectrometry, and computational simulation techniques," Nuclear Engineering and Design, Vol. 278, pp. 395-405. 
[9] Demkowicz, P.A., Harp, J.M., Winston, P.L., Ploger, S.A., 2013, Analysis of Fission Products on the AGR-1 Capsule Components, Idaho National Laboratory, INL/EXT-13-28483, March 2013.

[10] Hunn, J.D., Baldwin, C.A., Gerczak, T.J., Montgomery, F.C., Morris, R.N., Silva, C.M., Demkowicz P.A., Harp, J.M., Ploger, S.A., 2016, "Detection and analysis of particles with failed SiC in AGR-1 fuel compacts," Nuclear Engineering and Design, Vol. 306, pp. 36-46.

[11] Stempien, J.D. and Demkowicz, P.A., 2020, AGR-2 Irradiation Experiment Fission Product Mass Balance,” Idaho National Laboratory, INL/EXT-19-53559, Rev. 1, January 2020.

[12] Sterbentz, J. W., 2014, Preliminary JMOCUP As-Run Daily Depletion Calculation for the AGR-1 Experiment in ATR B-12 Position, ECAR-2066, Idaho National Laboratory, April 2014.

[13] Harp, J.M., Demkowicz, P.A., 2014, "Investigation of the Feasibility of Utilizing Gamma Emission Computed Tomography in Evaluating Fission Product Migration in Irradiated TRISO Fuel Experiments," Proceedings of HTR-2014, Weihai, China, October 27-31, 2014.

[14] Hawkes, G.L., 2014, AGR-2 Daily As-Run Thermal Analyses, Idaho National Laboratory, ECAR2476, Rev. 1, August 2014.

[15] Hunn, J.D., Baldwin, C.A., Montgomery, F.C., Gerczak, T.J. , Morris, R.N., Helmreich, G.W., Demkowicz, P.A., Harp, J.M., Stempien, J.D., 2016, "Initial Examination of Fuel Compacts and TRISO Particles from the U.S. AGR-2 Irradiation Test," Proceedings of the $8^{\text {th }}$ International Topical Meeting on High Temperature Reactor Technology(HTR2016), Las Vegas, Nevada, USA, November 6-10, 2016, Paper 18443.

[16] Morris, R.N., Baldwin, C.A., Hunn, J.D., Demkowicz, P.A., 2016, “Initial results from safety testing of US AGR-2 irradiation test fuel," Nuclear Engineering and Design 329 (2018) 124-133 https://doi.org/10.1016/j.nucengdes.2017.08.006.

[17] Collin, B.P., Demkowicz, P.A., Baldwin, C.A., Hunn, J.D., Harp, J.M., 2016, "Comparison of silver release predictions using PARFUME with results from the AGR-2 irradiation experiment," Proceedings of the $8^{\text {th }}$ International Topical Meeting on High Temperature Reactor Technology(HTR2016), Las Vegas, Nevada, USA, November 6-10, 2016, Paper 18579.

[18] Hunn, J.D., Baldwin, C.A., Montgomery, F.C., Gerczak, T.J., Morris, R.N., Helmreich, G.W., Demkowicz, P.A., Harp, J.M., and Stempien, J.D., 2018, "Initial Examination of Fuel Compacts and TRISO Particles from the US AGR-2 Irradiation Test," Nuclear Engineering and Design, Vol. 329, pp. 89-101.

[19] Hunn, J.D., Morris, R.N., Montgomery, F.C., Gerczak, T.J., Skitt, D.J., Baldwin, C.A., Dyer, J.A., Helmreich, G.W., Eckhart, B.D., Burns, Z.M., Demkowicz, P.A., and Stempien, J.D., 2018, "Post-irradiation Examination and Safety Testing of US AGR-2 Irradiation Test Compacts," Proceedings of the $9^{\text {th }}$ International Topical Meeting on High Temperature Reactor Technology (HTR-2018), Warsaw, Poland, October 8-10, 2018.

[20] Harp, J.M., 2016, Gamma Scanning of AGR-2 Compacts and Graphite Holders from Capsule 1, Idaho National Laboratory, INL/LTD-16-39736, September 2016.

[21] Harp, J.M., 2016, Gamma Scanning of AGR-2 Compacts and Graphite Holders from Capsule 4, Idaho National Laboratory, INL/LTD-16-39729, Rev. 0, September 2016. 


\section{Appendix A - Measured Activities for each Compact and Comparison to Simulations}

The total measured, decay-corrected compact inventories for Capsules 2, 3, 5, and 6 are listed in units of activity in the odd-numbered tables below. The absolute uncertainties for these activities are given in the even-numbered tables. The measured activities are compared to the calculated inventories at end of irradiation plus 1 day (October 17, 2013 at 11:00 AM MST) and plotted as a ratio of calculated over experimental (C/E) in Figure A.1.

Table A.1. Compact decay-corrected inventory for selected radioisotopes for AGR-2 UCO Capsule 2.

\begin{tabular}{|l|c|c|c|c|c|c|}
\hline \multirow{2}{*}{ Compact ID } & \multicolumn{7}{|c|}{ Activity (MBq) } \\
\cline { 2 - 7 } & Cs-137 & Cs-134 & Eu-154 & Ce-144 & Ru-106 & Zr-95 \\
\hline AGR-2 243 & $1.48 \mathrm{E}+04$ & $1.50 \mathrm{E}+04$ & $4.90 \mathrm{E}+02$ & $1.53 \mathrm{E}+05$ & $4.44 \mathrm{E}+04$ & $2.66 \mathrm{E}+05$ \\
\hline AGR-2 233 & $1.38 \mathrm{E}+04$ & $1.26 \mathrm{E}+04$ & $4.07 \mathrm{E}+02$ & $1.57 \mathrm{E}+05$ & $4.18 \mathrm{E}+04$ & $2.86 \mathrm{E}+05$ \\
\hline AGR-2 223 & $1.35 \mathrm{E}+04$ & $1.18 \mathrm{E}+04$ & $3.87 \mathrm{E}+02$ & $1.57 \mathrm{E}+05$ & $4.05 \mathrm{E}+04$ & $2.88 \mathrm{E}+05$ \\
\hline AGR-2 213 & $1.38 \mathrm{E}+04$ & $1.26 \mathrm{E}+04$ & $4.23 \mathrm{E}+02$ & $1.51 \mathrm{E}+05$ & $4.03 \mathrm{E}+04$ & $2.70 \mathrm{E}+05$ \\
\hline AGR-2 242 & $1.87 \mathrm{E}+04$ & $2.22 \mathrm{E}+04$ & $6.62 \mathrm{E}+02$ & $1.65 \mathrm{E}+05$ & $5.67 \mathrm{E}+04$ & $2.55 \mathrm{E}+05$ \\
\hline AGR-2 232 & $1.79 \mathrm{E}+04$ & $1.96 \mathrm{E}+04$ & $5.45 \mathrm{E}+02$ & $1.67 \mathrm{E}+05$ & $5.36 \mathrm{E}+04$ & $2.68 \mathrm{E}+05$ \\
\hline AGR-2 222 & $1.76 \mathrm{E}+04$ & $1.87 \mathrm{E}+04$ & $5.50 \mathrm{E}+02$ & $1.69 \mathrm{E}+05$ & $5.23 \mathrm{E}+04$ & $2.72 \mathrm{E}+05$ \\
\hline AGR-2 212 & $1.76 \mathrm{E}+04$ & $1.90 \mathrm{E}+04$ & $5.83 \mathrm{E}+02$ & $1.63 \mathrm{E}+05$ & $5.06 \mathrm{E}+04$ & $2.60 \mathrm{E}+05$ \\
\hline AGR-2 241 & $1.86 \mathrm{E}+04$ & $2.20 \mathrm{E}+04$ & $6.62 \mathrm{E}+02$ & $1.60 \mathrm{E}+05$ & $5.57 \mathrm{E}+04$ & $2.42 \mathrm{E}+05$ \\
\hline AGR-2 231 & $1.80 \mathrm{E}+04$ & $1.98 \mathrm{E}+04$ & $5.51 \mathrm{E}+02$ & $1.64 \mathrm{E}+05$ & $5.33 \mathrm{E}+04$ & $2.55 \mathrm{E}+05$ \\
\hline AGR-2 221 & $1.75 \mathrm{E}+04$ & $1.87 \mathrm{E}+04$ & $5.44 \mathrm{E}+02$ & $1.63 \mathrm{E}+05$ & $5.12 \mathrm{E}+04$ & $2.56 \mathrm{E}+05$ \\
\hline AGR-2 211 & $1.76 \mathrm{E}+04$ & $1.91 \mathrm{E}+04$ & $5.99 \mathrm{E}+02$ & $1.59 \mathrm{E}+05$ & $5.05 \mathrm{E}+04$ & $2.46 \mathrm{E}+05$ \\
\hline
\end{tabular}

Table A.2. Compact decay-corrected inventory uncertainty for selected radioisotopes for AGR-2 UCO Capsule 2.

\begin{tabular}{|l|l|l|l|l|l|l|}
\hline \multirow{2}{*}{ Compact ID } & \multicolumn{7}{|c|}{ Activity (MBq) } \\
\cline { 2 - 7 } & Cs-137 & Cs-134 & Eu-154 & Ce-144 & Ru-106 & Zr-95 \\
\hline AGR-2 243 & $2.95 \mathrm{E}+01$ & $4.62 \mathrm{E}+01$ & $5.14 \mathrm{E}+00$ & $6.92 \mathrm{E}+02$ & $1.44 \mathrm{E}+02$ & $1.01 \mathrm{E}+03$ \\
\hline AGR-2 233 & $2.42 \mathrm{E}+01$ & $3.88 \mathrm{E}+01$ & $4.50 \mathrm{E}+00$ & $7.05 \mathrm{E}+02$ & $1.41 \mathrm{E}+02$ & $1.31 \mathrm{E}+03$ \\
\hline AGR-2 223 & $2.79 \mathrm{E}+01$ & $3.48 \mathrm{E}+01$ & $4.75 \mathrm{E}+00$ & $8.13 \mathrm{E}+02$ & $1.37 \mathrm{E}+02$ & $1.10 \mathrm{E}+03$ \\
\hline AGR-2 213 & $2.88 \mathrm{E}+01$ & $3.49 \mathrm{E}+01$ & $4.50 \mathrm{E}+00$ & $6.42 \mathrm{E}+02$ & $1.19 \mathrm{E}+02$ & $1.13 \mathrm{E}+03$ \\
\hline AGR-2 242 & $2.91 \mathrm{E}+01$ & $7.23 \mathrm{E}+01$ & $6.60 \mathrm{E}+00$ & $8.39 \mathrm{E}+02$ & $1.68 \mathrm{E}+02$ & $1.34 \mathrm{E}+03$ \\
\hline AGR-2 232 & $2.81 \mathrm{E}+01$ & $6.27 \mathrm{E}+01$ & $6.40 \mathrm{E}+00$ & $7.51 \mathrm{E}+02$ & $1.75 \mathrm{E}+02$ & $1.32 \mathrm{E}+03$ \\
\hline AGR-2 222 & $1.56 \mathrm{E}+02$ & $1.89 \mathrm{E}+02$ & $1.80 \mathrm{E}+01$ & $2.41 \mathrm{E}+03$ & $5.20 \mathrm{E}+02$ & $1.81 \mathrm{E}+03$ \\
\hline AGR-2 212 & $1.16 \mathrm{E}+02$ & $1.98 \mathrm{E}+02$ & $1.84 \mathrm{E}+01$ & $2.78 \mathrm{E}+03$ & $5.70 \mathrm{E}+02$ & $1.66 \mathrm{E}+03$ \\
\hline AGR-2 241 & $4.39 \mathrm{E}+01$ & $6.57 \mathrm{E}+01$ & $6.98 \mathrm{E}+00$ & $9.29 \mathrm{E}+02$ & $2.13 \mathrm{E}+02$ & $1.24 \mathrm{E}+03$ \\
\hline AGR-2 231 & $4.62 \mathrm{E}+01$ & $5.30 \mathrm{E}+01$ & $6.35 \mathrm{E}+00$ & $8.47 \mathrm{E}+02$ & $1.49 \mathrm{E}+02$ & $1.38 \mathrm{E}+03$ \\
\hline AGR-2 221 & $4.36 \mathrm{E}+01$ & $5.24 \mathrm{E}+01$ & $5.88 \mathrm{E}+00$ & $8.77 \mathrm{E}+02$ & $1.38 \mathrm{E}+02$ & $1.29 \mathrm{E}+03$ \\
\hline AGR-2 211 & $4.61 \mathrm{E}+01$ & $5.46 \mathrm{E}+01$ & $6.36 \mathrm{E}+00$ & $7.69 \mathrm{E}+02$ & $1.45 \mathrm{E}+02$ & $1.00 \mathrm{E}+03$ \\
\hline
\end{tabular}


Table A.3. Compact decay corrected inventory for selected radioisotopes for AGR-2 $\mathrm{UO}_{2}$ Capsule 3

\begin{tabular}{|l|l|l|l|l|l|l|}
\hline \multirow{2}{*}{ Compact ID } & \multicolumn{7}{|c|}{ Activity $(\mathrm{MBq})$} \\
\cline { 2 - 7 } & Cs-137 & Cs-134 & Eu-154 & Ce-144 & Ru-106 & Zr-95 \\
\hline AGR-2 343 & $1.06 \mathrm{E}+04$ & $1.15 \mathrm{E}+04$ & $3.97 \mathrm{E}+02$ & $1.03 \mathrm{E}+05$ & $4.00 \mathrm{E}+04$ & $1.65 \mathrm{E}+05$ \\
\hline AGR-2 333 & $1.03 \mathrm{E}+04$ & $1.04 \mathrm{E}+04$ & $3.62 \mathrm{E}+02$ & $1.07 \mathrm{E}+05$ & $3.99 \mathrm{E}+04$ & $1.77 \mathrm{E}+05$ \\
\hline AGR-2 323 & $1.01 \mathrm{E}+04$ & $1.02 \mathrm{E}+04$ & $3.53 \mathrm{E}+02$ & $1.05 \mathrm{E}+05$ & $3.86 \mathrm{E}+04$ & $1.73 \mathrm{E}+05$ \\
\hline AGR-2 313 & $1.05 \mathrm{E}+04$ & $1.11 \mathrm{E}+04$ & $3.86 \mathrm{E}+02$ & $1.02 \mathrm{E}+05$ & $3.91 \mathrm{E}+04$ & $1.65 \mathrm{E}+05$ \\
\hline AGR-2 342 & $1.21 \mathrm{E}+04$ & $1.52 \mathrm{E}+04$ & $4.88 \mathrm{E}+02$ & $1.00 \mathrm{E}+05$ & $4.78 \mathrm{E}+04$ & $1.47 \mathrm{E}+05$ \\
\hline AGR-2 332 & $1.17 \mathrm{E}+04$ & $1.40 \mathrm{E}+04$ & $4.47 \mathrm{E}+02$ & $1.01 \mathrm{E}+05$ & $4.59 \mathrm{E}+04$ & $1.51 \mathrm{E}+05$ \\
\hline AGR-2 322 & $1.16 \mathrm{E}+04$ & $1.39 \mathrm{E}+04$ & $4.46 \mathrm{E}+02$ & $1.01 \mathrm{E}+05$ & $4.49 \mathrm{E}+04$ & $1.48 \mathrm{E}+05$ \\
\hline AGR-2 312 & $1.19 \mathrm{E}+04$ & $1.46 \mathrm{E}+04$ & $4.64 \mathrm{E}+02$ & $9.90 \mathrm{E}+04$ & $4.62 \mathrm{E}+04$ & $1.44 \mathrm{E}+05$ \\
\hline AGR-2 341 & $1.20 \mathrm{E}+04$ & $1.51 \mathrm{E}+04$ & $4.80 \mathrm{E}+02$ & $9.74 \mathrm{E}+04$ & $4.60 \mathrm{E}+04$ & $1.40 \mathrm{E}+05$ \\
\hline AGR-2 331 & $1.18 \mathrm{E}+04$ & $1.42 \mathrm{E}+04$ & $4.47 \mathrm{E}+02$ & $1.01 \mathrm{E}+05$ & $4.51 \mathrm{E}+04$ & $1.45 \mathrm{E}+05$ \\
\hline AGR-2 321 & $1.20 \mathrm{E}+04$ & $1.43 \mathrm{E}+04$ & $4.53 \mathrm{E}+02$ & $1.02 \mathrm{E}+05$ & $4.64 \mathrm{E}+04$ & $1.57 \mathrm{E}+05$ \\
\hline AGR-2 311 & $1.22 \mathrm{E}+04$ & $1.50 \mathrm{E}+04$ & $4.76 \mathrm{E}+02$ & $9.94 \mathrm{E}+04$ & $4.68 \mathrm{E}+04$ & $1.48 \mathrm{E}+05$ \\
\hline
\end{tabular}

Table A.4. Compact decay corrected inventory uncertainty for selected radioisotopes for AGR-2 $\mathrm{UO}_{2}$ Capsule 3

\begin{tabular}{|l|l|l|l|l|l|l|}
\hline \multirow{2}{*}{ Compact ID } & \multicolumn{7}{|c|}{ Activity $(\mathrm{MBq})$} \\
\cline { 2 - 8 } & Cs-137 & Cs-134 & Eu-154 & Ce-144 & Ru-106 & Zr-95 \\
\hline AGR-2 343 & $3.22 \mathrm{E}+01$ & $4.56 \mathrm{E}+01$ & $4.31 \mathrm{E}+00$ & $7.35 \mathrm{E}+02$ & $1.53 \mathrm{E}+02$ & $7.13 \mathrm{E}+02$ \\
\hline AGR-2 333 & $3.16 \mathrm{E}+01$ & $4.31 \mathrm{E}+01$ & $4.08 \mathrm{E}+00$ & $5.72 \mathrm{E}+02$ & $1.95 \mathrm{E}+02$ & $6.75 \mathrm{E}+02$ \\
\hline AGR-2 323 & $2.73 \mathrm{E}+01$ & $4.29 \mathrm{E}+01$ & $4.30 \mathrm{E}+00$ & $5.71 \mathrm{E}+02$ & $1.24 \mathrm{E}+02$ & $6.82 \mathrm{E}+02$ \\
\hline AGR-2 313 & $2.93 \mathrm{E}+01$ & $4.31 \mathrm{E}+01$ & $4.15 \mathrm{E}+00$ & $5.17 \mathrm{E}+02$ & $1.34 \mathrm{E}+02$ & $5.95 \mathrm{E}+02$ \\
\hline AGR-2 342 & $3.35 \mathrm{E}+01$ & $5.47 \mathrm{E}+01$ & $4.54 \mathrm{E}+00$ & $5.24 \mathrm{E}+02$ & $2.31 \mathrm{E}+02$ & $6.87 \mathrm{E}+02$ \\
\hline AGR-2 332 & $3.62 \mathrm{E}+01$ & $5.42 \mathrm{E}+01$ & $4.81 \mathrm{E}+00$ & $5.97 \mathrm{E}+02$ & $2.18 \mathrm{E}+02$ & $6.21 \mathrm{E}+02$ \\
\hline AGR-2 322 & $1.04 \mathrm{E}+02$ & $1.69 \mathrm{E}+02$ & $1.50 \mathrm{E}+01$ & $1.90 \mathrm{E}+03$ & $5.77 \mathrm{E}+02$ & $6.42 \mathrm{E}+02$ \\
\hline AGR-2 312 & $5.92 \mathrm{E}+01$ & $8.58 \mathrm{E}+01$ & $7.28 \mathrm{E}+00$ & $9.17 \mathrm{E}+02$ & $3.57 \mathrm{E}+02$ & $4.75 \mathrm{E}+02$ \\
\hline AGR-2 341 & $5.92 \mathrm{E}+01$ & $8.58 \mathrm{E}+01$ & $4.91 \mathrm{E}+00$ & $5.62 \mathrm{E}+02$ & $2.83 \mathrm{E}+02$ & $9.33 \mathrm{E}+02$ \\
\hline AGR-2 331 & $1.02 \mathrm{E}+02$ & $9.05 \mathrm{E}+01$ & $4.02 \mathrm{E}+00$ & $6.66 \mathrm{E}+02$ & $2.82 \mathrm{E}+02$ & $1.11 \mathrm{E}+03$ \\
\hline AGR-2 321 & $1.12 \mathrm{E}+02$ & $9.92 \mathrm{E}+01$ & $4.73 \mathrm{E}+00$ & $2.01 \mathrm{E}+03$ & $3.64 \mathrm{E}+02$ & $1.28 \mathrm{E}+03$ \\
\hline AGR-2 311 & $4.15 \mathrm{E}+01$ & $3.36 \mathrm{E}+01$ & $4.80 \mathrm{E}+00$ & $6.73 \mathrm{E}+02$ & $1.96 \mathrm{E}+02$ & $1.94 \mathrm{E}+03$ \\
\hline
\end{tabular}


Table A.5. Compact decay corrected inventory for selected radioisotopes for AGR-2 UCO Capsule 5.

\begin{tabular}{|l|l|l|l|l|l|l|}
\hline \multirow{2}{*}{ Compact ID } & \multicolumn{7}{|c|}{ Activity $(\mathrm{MBq})$} \\
\cline { 2 - 7 } & Cs-137 & Cs-134 & Eu-154 & Ce-144 & Ru-106 & Zr-95 \\
\hline AGR-2 543 & $1.38 \mathrm{E}+04$ & $1.16 \mathrm{E}+04$ & $3.98 \mathrm{E}+02$ & $1.58 \mathrm{E}+05$ & $3.89 \mathrm{E}+04$ & $2.84 \mathrm{E}+05$ \\
\hline AGR-2 533 & $1.35 \mathrm{E}+04$ & $1.08 \mathrm{E}+04$ & $3.63 \mathrm{E}+02$ & $1.65 \mathrm{E}+05$ & $3.95 \mathrm{E}+04$ & $3.04 \mathrm{E}+05$ \\
\hline AGR-2 523 & $1.39 \mathrm{E}+04$ & $1.17 \mathrm{E}+04$ & $3.97 \mathrm{E}+02$ & $1.66 \mathrm{E}+05$ & $4.12 \mathrm{E}+04$ & $2.99 \mathrm{E}+05$ \\
\hline AGR-2 513 & $1.50 \mathrm{E}+04$ & $1.44 \mathrm{E}+04$ & $4.86 \mathrm{E}+02$ & $1.61 \mathrm{E}+05$ & $4.36 \mathrm{E}+04$ & $2.69 \mathrm{E}+05$ \\
\hline AGR-2 542 & $1.62 \mathrm{E}+04$ & $1.69 \mathrm{E}+04$ & $5.33 \mathrm{E}+02$ & $1.55 \mathrm{E}+05$ & $4.56 \mathrm{E}+04$ & $2.45 \mathrm{E}+05$ \\
\hline AGR-2 532 & $1.65 \mathrm{E}+04$ & $1.67 \mathrm{E}+04$ & $5.24 \mathrm{E}+02$ & $1.64 \mathrm{E}+05$ & $4.76 \mathrm{E}+04$ & $2.58 \mathrm{E}+05$ \\
\hline AGR-2 522 & $1.68 \mathrm{E}+04$ & $1.79 \mathrm{E}+04$ & $5.61 \mathrm{E}+02$ & $1.63 \mathrm{E}+05$ & $4.80 \mathrm{E}+04$ & $2.52 \mathrm{E}+05$ \\
\hline AGR-2 512 & $1.75 \mathrm{E}+04$ & $2.04 \mathrm{E}+04$ & $6.25 \mathrm{E}+02$ & $1.56 \mathrm{E}+05$ & $5.11 \mathrm{E}+04$ & $2.29 \mathrm{E}+05$ \\
\hline AGR-2 541 & $1.62 \mathrm{E}+04$ & $1.64 \mathrm{E}+04$ & $5.26 \mathrm{E}+02$ & $1.54 \mathrm{E}+05$ & $4.45 \mathrm{E}+04$ & $2.35 \mathrm{E}+05$ \\
\hline AGR-2 531 & $1.62 \mathrm{E}+04$ & $1.62 \mathrm{E}+04$ & $5.13 \mathrm{E}+02$ & $1.61 \mathrm{E}+05$ & $4.56 \mathrm{E}+04$ & $2.49 \mathrm{E}+05$ \\
\hline AGR-2 521 & $1.67 \mathrm{E}+04$ & $1.73 \mathrm{E}+04$ & $5.47 \mathrm{E}+02$ & $1.61 \mathrm{E}+05$ & $4.76 \mathrm{E}+04$ & $2.44 \mathrm{E}+05$ \\
\hline AGR-2 511 & $1.80 \mathrm{E}+04$ & $2.02 \mathrm{E}+04$ & $6.33 \mathrm{E}+02$ & $1.59 \mathrm{E}+05$ & $5.13 \mathrm{E}+04$ & $2.30 \mathrm{E}+05$ \\
\hline
\end{tabular}

Table A.6. Compact decay corrected inventory uncertainty for selected radioisotopes for AGR-2 UCO Capsule 5.

\begin{tabular}{|l|l|l|l|l|l|l|}
\hline \multirow{2}{*}{ Compact ID } & \multicolumn{7}{|c|}{ Activity $(\mathrm{MBq})$} \\
\cline { 2 - 7 } & Cs-137 & Cs-134 & Eu-154 & Ce-144 & Ru-106 & Zr-95 \\
\hline AGR-2 543 & $7.70 \mathrm{E}+01$ & $1.16 \mathrm{E}+02$ & $4.67 \mathrm{E}+00$ & $1.11 \mathrm{E}+03$ & $2.18 \mathrm{E}+02$ & $1.70 \mathrm{E}+03$ \\
\hline AGR-2 533 & $7.63 \mathrm{E}+01$ & $1.08 \mathrm{E}+02$ & $5.01 \mathrm{E}+00$ & $1.19 \mathrm{E}+03$ & $2.44 \mathrm{E}+02$ & $1.96 \mathrm{E}+03$ \\
\hline AGR-2 523 & $1.03 \mathrm{E}+02$ & $8.71 \mathrm{E}+01$ & $4.75 \mathrm{E}+00$ & $1.08 \mathrm{E}+03$ & $2.76 \mathrm{E}+02$ & $2.10 \mathrm{E}+03$ \\
\hline AGR-2 513 & $9.66 \mathrm{E}+01$ & $1.14 \mathrm{E}+02$ & $5.19 \mathrm{E}+00$ & $1.27 \mathrm{E}+03$ & $3.17 \mathrm{E}+02$ & $1.80 \mathrm{E}+03$ \\
\hline AGR-2 542 & $1.17 \mathrm{E}+02$ & $1.93 \mathrm{E}+02$ & $5.68 \mathrm{E}+00$ & $1.16 \mathrm{E}+03$ & $3.07 \mathrm{E}+02$ & $1.64 \mathrm{E}+03$ \\
\hline AGR-2 532 & $8.85 \mathrm{E}+01$ & $1.42 \mathrm{E}+02$ & $5.01 \mathrm{E}+00$ & $1.20 \mathrm{E}+03$ & $3.00 \mathrm{E}+02$ & $1.52 \mathrm{E}+03$ \\
\hline AGR-2 522 & $2.82 \mathrm{E}+02$ & $4.05 \mathrm{E}+02$ & $1.57 \mathrm{E}+01$ & $3.01 \mathrm{E}+03$ & $9.96 \mathrm{E}+02$ & $1.56 \mathrm{E}+03$ \\
\hline AGR-2 512 & $3.05 \mathrm{E}+02$ & $4.86 \mathrm{E}+02$ & $1.38 \mathrm{E}+01$ & $2.73 \mathrm{E}+03$ & $7.32 \mathrm{E}+02$ & $1.77 \mathrm{E}+03$ \\
\hline AGR-2 541 & $1.04 \mathrm{E}+02$ & $1.87 \mathrm{E}+02$ & $5.83 \mathrm{E}+00$ & $1.28 \mathrm{E}+03$ & $3.23 \mathrm{E}+02$ & $1.34 \mathrm{E}+03$ \\
\hline AGR-2 531 & $1.20 \mathrm{E}+02$ & $1.62 \mathrm{E}+02$ & $5.31 \mathrm{E}+00$ & $1.17 \mathrm{E}+03$ & $2.92 \mathrm{E}+02$ & $1.82 \mathrm{E}+03$ \\
\hline AGR-2 521 & $9.84 \mathrm{E}+01$ & $1.89 \mathrm{E}+02$ & $5.46 \mathrm{E}+00$ & $1.23 \mathrm{E}+03$ & $3.09 \mathrm{E}+02$ & $1.78 \mathrm{E}+03$ \\
\hline AGR-2 511 & $9.52 \mathrm{E}+01$ & $1.11 \mathrm{E}+02$ & $5.85 \mathrm{E}+00$ & $1.36 \mathrm{E}+03$ & $2.92 \mathrm{E}+02$ & $1.49 \mathrm{E}+03$ \\
\hline
\end{tabular}


Table A.7. Compact decay corrected inventory for selected radioisotopes for AGR-2 UCO Capsule 6.

\begin{tabular}{|l|l|l|l|l|l|l|}
\hline \multirow{2}{*}{ Compact ID } & \multicolumn{7}{|c|}{ Activity $(\mathrm{MBq})$} \\
\cline { 2 - 7 } & Cs-137 & Cs-134 & Eu-154 & Ce-144 & Ru-106 & Zr-95 \\
\hline AGR-2 643 & $9.80 \mathrm{E}+03$ & $5.66 \mathrm{E}+03$ & $2.02 \mathrm{E}+02$ & $1.18 \mathrm{E}+05$ & $2.28 \mathrm{E}+04$ & $2.35 \mathrm{E}+05$ \\
\hline AGR-2 633 & $9.74 \mathrm{E}+03$ & $5.61 \mathrm{E}+03$ & $1.96 \mathrm{E}+02$ & $1.24 \mathrm{E}+05$ & $2.42 \mathrm{E}+04$ & $2.55 \mathrm{E}+05$ \\
\hline AGR-2 623 & $1.07 \mathrm{E}+04$ & $6.85 \mathrm{E}+03$ & $2.38 \mathrm{E}+02$ & $1.33 \mathrm{E}+05$ & $2.75 \mathrm{E}+04$ & $2.65 \mathrm{E}+05$ \\
\hline AGR-2 613 & $1.23 \mathrm{E}+04$ & $9.15 \mathrm{E}+03$ & $3.26 \mathrm{E}+02$ & $1.37 \mathrm{E}+05$ & $3.13 \mathrm{E}+04$ & $2.56 \mathrm{E}+05$ \\
\hline AGR-2 642 & $1.24 \mathrm{E}+04$ & $8.60 \mathrm{E}+03$ & $3.06 \mathrm{E}+02$ & $1.31 \mathrm{E}+05$ & $2.84 \mathrm{E}+04$ & $2.37 \mathrm{E}+05$ \\
\hline AGR-2 632 & $1.28 \mathrm{E}+04$ & $9.04 \mathrm{E}+03$ & $3.13 \mathrm{E}+02$ & $1.38 \mathrm{E}+05$ & $3.06 \mathrm{E}+04$ & $2.52 \mathrm{E}+05$ \\
\hline AGR-2 622 & $1.36 \mathrm{E}+04$ & $1.06 \mathrm{E}+04$ & $3.57 \mathrm{E}+02$ & $1.41 \mathrm{E}+05$ & $3.37 \mathrm{E}+04$ & $2.51 \mathrm{E}+05$ \\
\hline AGR-2 612 & $1.48 \mathrm{E}+04$ & $1.32 \mathrm{E}+04$ & $4.44 \mathrm{E}+02$ & $1.41 \mathrm{E}+05$ & $3.74 \mathrm{E}+04$ & $2.40 \mathrm{E}+05$ \\
\hline AGR-2 641 & $1.24 \mathrm{E}+04$ & $8.55 \mathrm{E}+03$ & $3.02 \mathrm{E}+02$ & $1.28 \mathrm{E}+05$ & $2.76 \mathrm{E}+04$ & $2.24 \mathrm{E}+05$ \\
\hline AGR-2 631 & $1.27 \mathrm{E}+04$ & $8.92 \mathrm{E}+03$ & $3.11 \mathrm{E}+02$ & $1.34 \mathrm{E}+05$ & $2.98 \mathrm{E}+04$ & $2.33 \mathrm{E}+05$ \\
\hline AGR-2 621 & $1.36 \mathrm{E}+04$ & $1.05 \mathrm{E}+04$ & $3.57 \mathrm{E}+02$ & $1.37 \mathrm{E}+05$ & $3.29 \mathrm{E}+04$ & $2.33 \mathrm{E}+05$ \\
\hline AGR-2 611 & $1.47 \mathrm{E}+04$ & $1.30 \mathrm{E}+04$ & $4.40 \mathrm{E}+02$ & $1.37 \mathrm{E}+05$ & $3.66 \mathrm{E}+04$ & $2.22 \mathrm{E}+05$ \\
\hline
\end{tabular}

Table A.8. Compact decay corrected inventory uncertainty for selected radioisotopes for AGR-2 UCO Capsule 6.

\begin{tabular}{|l|c|l|l|l|l|c|}
\hline \multirow{2}{*}{ Compact ID } & \multicolumn{7}{|c|}{ Activity $(\mathrm{MBq})$} \\
\cline { 2 - 7 } & Cs-137 & Cs-134 & Eu-154 & Ce-144 & Ru-106 & Zr-95 \\
\hline AGR-2 643 & $5.20 \mathrm{E}+01$ & $6.47 \mathrm{E}+01$ & $3.35 \mathrm{E}+00$ & $8.32 \mathrm{E}+02$ & $1.37 \mathrm{E}+02$ & $2.48 \mathrm{E}+03$ \\
\hline AGR-2 633 & $4.48 \mathrm{E}+01$ & $6.90 \mathrm{E}+01$ & $3.27 \mathrm{E}+00$ & $1.09 \mathrm{E}+03$ & $1.53 \mathrm{E}+02$ & $2.58 \mathrm{E}+03$ \\
\hline AGR-2 623 & $7.41 \mathrm{E}+01$ & $9.32 \mathrm{E}+01$ & $3.55 \mathrm{E}+00$ & $8.32 \mathrm{E}+02$ & $1.82 \mathrm{E}+02$ & $3.17 \mathrm{E}+03$ \\
\hline AGR-2 613 & $8.55 \mathrm{E}+01$ & $6.57 \mathrm{E}+01$ & $4.27 \mathrm{E}+00$ & $1.05 \mathrm{E}+03$ & $2.11 \mathrm{E}+02$ & $2.69 \mathrm{E}+03$ \\
\hline AGR-2 642 & $7.12 \mathrm{E}+01$ & $7.89 \mathrm{E}+01$ & $4.02 \mathrm{E}+00$ & $1.17 \mathrm{E}+03$ & $1.98 \mathrm{E}+02$ & $2.82 \mathrm{E}+03$ \\
\hline AGR-2 632 & $6.37 \mathrm{E}+01$ & $6.09 \mathrm{E}+01$ & $4.39 \mathrm{E}+00$ & $1.12 \mathrm{E}+03$ & $2.14 \mathrm{E}+02$ & $2.44 \mathrm{E}+03$ \\
\hline AGR-2 622 & $2.10 \mathrm{E}+02$ & $1.40 \mathrm{E}+02$ & $8.69 \mathrm{E}+00$ & $2.02 \mathrm{E}+03$ & $4.27 \mathrm{E}+02$ & $2.83 \mathrm{E}+03$ \\
\hline AGR-2 612 & $1.47 \mathrm{E}+02$ & $1.21 \mathrm{E}+02$ & $7.14 \mathrm{E}+00$ & $2.03 \mathrm{E}+03$ & $3.67 \mathrm{E}+02$ & $1.87 \mathrm{E}+03$ \\
\hline AGR-2 641 & $7.90 \mathrm{E}+01$ & $8.89 \mathrm{E}+01$ & $4.90 \mathrm{E}+00$ & $1.23 \mathrm{E}+03$ & $2.42 \mathrm{E}+02$ & $2.78 \mathrm{E}+03$ \\
\hline AGR-2 631 & $6.88 \mathrm{E}+01$ & $1.04 \mathrm{E}+02$ & $3.85 \mathrm{E}+00$ & $1.16 \mathrm{E}+03$ & $1.99 \mathrm{E}+02$ & $2.80 \mathrm{E}+03$ \\
\hline AGR-2 621 & $7.48 \mathrm{E}+00$ & $6.04 \mathrm{E}+00$ & $7.83 \mathrm{E}-01$ & $1.91 \mathrm{E}+02$ & $2.04 \mathrm{E}+01$ & $5.00 \mathrm{E}+02$ \\
\hline AGR-2 611 & $6.12 \mathrm{E}+01$ & $6.21 \mathrm{E}+01$ & $4.05 \mathrm{E}+00$ & $9.48 \mathrm{E}+02$ & $2.25 \mathrm{E}+02$ & $2.46 \mathrm{E}+03$ \\
\hline
\end{tabular}




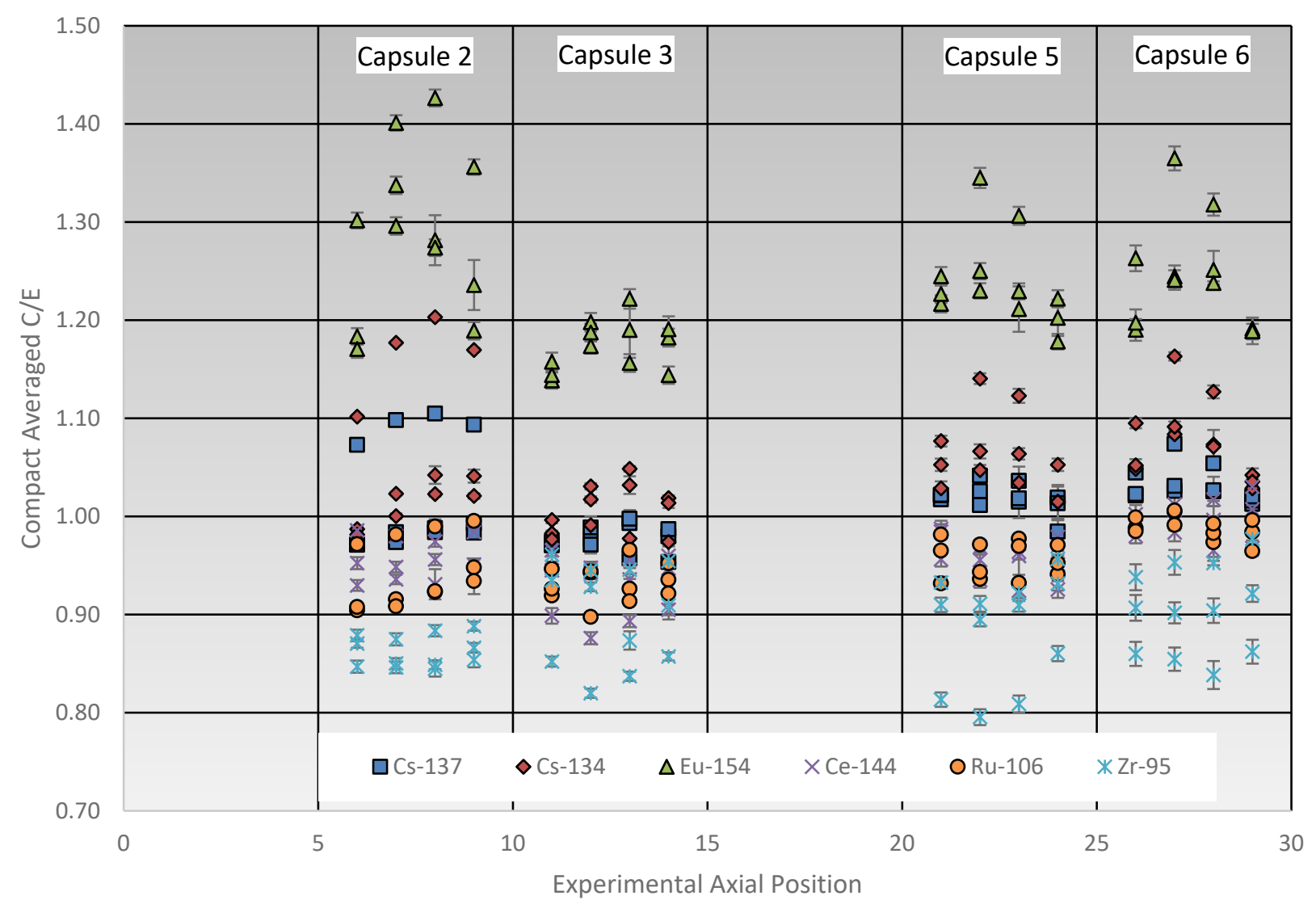

Figure A.1. C/E for AGR-2 compacts from Capsule 2, 3, 5, and 6. 